
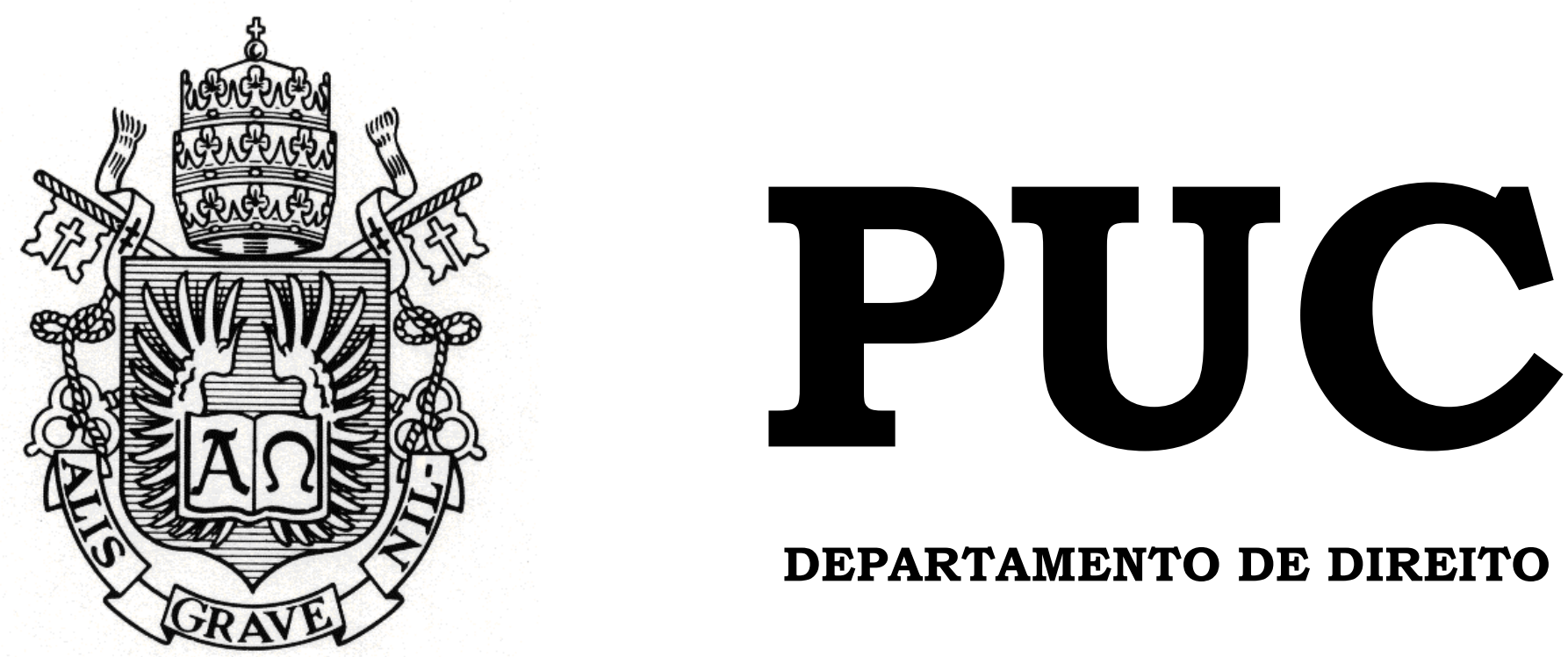

DEPARTAMENTO DE DIREITO

\title{
A NOVA LEI DE REGULARIZAÇÃO FUNDIÁRIA E SEUS IMPACTOS NA REFORMA AGRÁRIA
}

por

MARIA ISABEL MATOS TANCREDO

ORIENTADOR(A): VIRGINIA TOTTI GUIMARÃES

2018.2

PONTIFÍCIA UNIVERSIDADE CATÓLICA DO RIO DE JANEIRO

RUA MARQUÊS DE SÃO VICENTE, 225 - CEP 22453-900

RIO DE JANEIRO - BRASIL 


\section{A NOVA LEI DE REGULARIZAÇÃO FUNDIÁRIA E SEUS IMPACTOS NA REFORMA AGRÁRIA}

por

MARIA ISABEL MATOS TANCREDO

Monografia apresentada ao Departamento de Direito da Pontificia Universidade Católica do Rio de Janeiro (PUC-Rio) para a obtenção do Título de Bacharel em Direito.

Orientador(a): Virginia Totti Guimarães 
À minha avó Hilda, onde quer que esteja, sinto sua torcida, afeto e carinho. Todos os meus passos são em homenagem à sua memória e ao seu sorriso. 


\section{Agradecimentos}

Não poderia começar por outro agradecimento senão à força que peço emprestado das mulheres guerreiras de minha família, em especial minha mãe, Edneia, com quem aprendi e tento reproduzir diariamente o maior de seus ensinamentos, seja através de seu livro, seja através de suas ações cotidianas: a solidariedade.

Mantendo a extensão do meu obrigado à todas as outras, quero agradecer à minha tia Ester, pelo exemplo de resistência aguerrida e amor à vida. O que você viveu e vive me mostra a potência do desejo de ser feliz. Da sua criação só poderia surgir uma filha inspiradora, sensível e dona de si. Aqui agradeço à Ana, pelo exemplo de cuidado, afeto e persistência. Não há caminho que você não possa trilhar.

Agradeço ao meu pai, João, que me inspira a indignação e o desejo de construir um novo amanhã. Obrigada por toda a sensibilidade e companheirismo que compartilhamos, nada haveria em mim sem você ao lado, meu exemplo de luta, sem jamais perder a ternura.

Aos companheiros e companheiras do Assentamento Roseli Nunes, em Piraí, no Rio de Janeiro, onde puder aprender o sentido da vida, da terra, da cooperação. Momento esse que só pude ter após conhecer e me tornar mais uma grande admiradora de Mariana Trotta, quem permitiu e embalou meu interesse pelo tema desde a sorte de tê-la como professora no primeiro período na PUC-Rio.

Estendo o agradecimento a todos e todas do grupo Terras e Lutas, com vocês aprendi o significado de cursar direito e dividi as angústias de um curso que não se volta à transformação. Com vocês continuar foi possível e preciso. Agradeço também ao Adriano Pilatti que, para além dos valiosos ensinamentos em qualquer dos espaços que com ele dividi, me convenceu cheio de afeto da importância de cuidar de si.

Agradeço à Virgínia Totti, não apenas pelo brilhante exemplo de pesquisadora, professora, mulher, mãe, mas também pela paciente e cuidadosa orientação que permitiu que esse trabalho fosse realizado, a começar pela inspiração do tema que surgiu com uma excepcional palestra organizada por ela.

Aos queridos amigos e amigas que nasceram com a Primavera, Julia, Jasmine, Camila, Joaquim, Johan, Rayan, Chicão e nosso novato Zamorano, com vocês mergulhei no significado de família, na saúde e na doença. Obrigada por todos os dias.

Finalmente, ao meu companheiro, Luis Zamorano, o grande responsável pela força necessária para a conclusão do presente trabalho, frente às adversidades que minha saúde impõe. Sua permanente torcida, companheirismo, carinho, suporte, amor e afeto é o que faz o meu caminhar possível. É no seu sorriso que encontro a certeza de continuar, resistir e sonhar. Com a sorte de te ter, seguimos sempre. 


\section{Resumo}

A presente monografia tem como objetivo apresentar criticamente as inovações e mudanças trazidas no campo da regularização fundiária, com foco na reforma agrária, pela Lei 13.465/17. A partir da compreensão das diferentes compreensões e aplicações da política de reforma agrária ao longo dos marcos históricos da ditadura militar, processo constituinte, normas positivadas na Constituição e conjuntura contemporânea, busca-se propiciar um terreno mais fértil para análise dos desafios e alterações impostas pelo novo marco legal. Assim, o trabalho examinou a tramitação da lei, a inclusão do requisito da temporalidade como elemento que solitário permite a consolidação dos projetos de assentamento, o conceito e efeitos da chamada "conclusão de investimentos", as formas de titulação dos assentados, a autorização para realização de contratos de integração, as alterações na seleção de beneficiários do Programa Nacional de Reforma Agrária, a previsão de pagamento em dinheiro pelos imóveis rurais adquiridos por meio de compra e venda ou arrematação judicial para fins de reforma agrária e, por fim, a Ação Direta de Inconstitucionalidade movida pelo Procurador Geral da República em face da lei. Nesse contexto, tornou-se possível perceber os efeitos de reconcentração fundiária que fizeram com que a lei fosse conhecida como potencializadora de uma contrarreforma agrária.

\section{Palavras-chave}

Direito agrário; regularização fundiária; reforma agrária; Lei 13.465/17; assentamentos rurais; 


\section{Sumário}

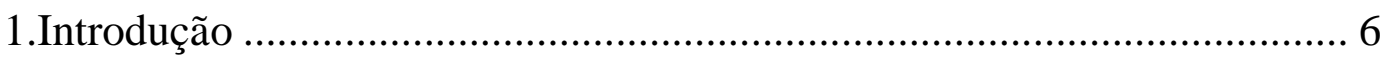

2. A noção de Reforma Agrária e seus marcos normativos no Brasil .......... 8

2.1. A modernização conservadora e o advento da "empresa rural": reforma

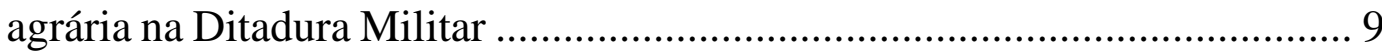

2.2. Redemocratização e Processo Constituinte de 1987-88 ……………..... 17

2.3. A reforma agrária na Constituição de 1988 ......................................... 27

2.4. A reforma agrária no Século XXI: uma conversação complexa ........... 30

3. Lei 13.465/17: alterações normativas e repercussões na política de reforma

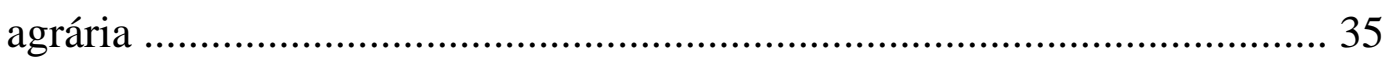

3.1. Conjuntura política e desmonte de políticas públicas ............................ 35

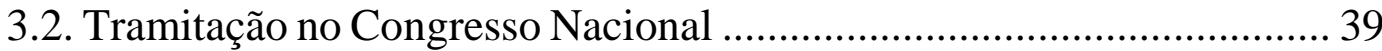

3.3. Mudanças e inovações da Lei 13.465/17 ............................................... 43

3.3.1. Critério para consolidação dos projetos de assentamento e a "conclusão

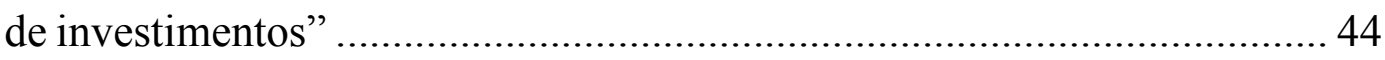

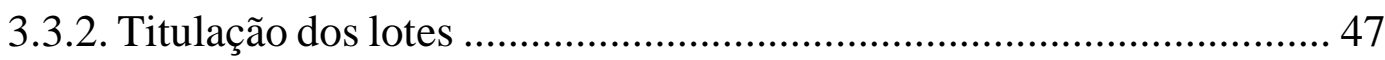

3.3.3. Seleção de beneficiários do programa de reforma agrária e a municipalização do procedimento ............................................................... 54

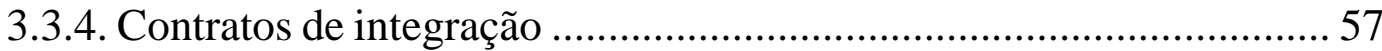

3.3.5. Pagamento em dinheiro na compra e venda de imóveis para reforma

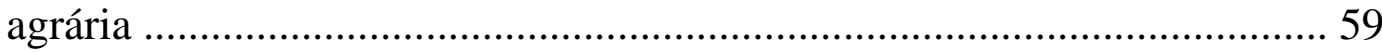

3.4. Ação Direta de Inconstitucionalidade (ADI 5771) ................................. 61

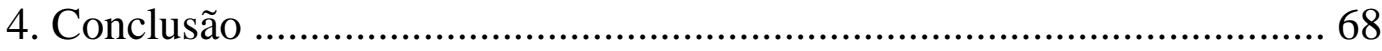

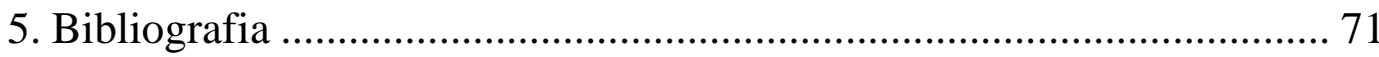




\section{Introdução}

Em dezembro de 2016, o Presidente Michel Temer editou a Medida Provisória $\mathrm{n}^{\mathrm{o}} 759$, que alterava uma série de dispositivos tocantes a regularização fundiária rural e urbana, sem que houvesse qualquer discussão conjunta com a sociedade civil a esse respeito.

Assim, inaugurou-se um intenso processo de disputas entre, de um lado, o governo e membros do agronegócio e, de outro, movimentos sociais de diversas frentes na defesa e oposição, respectivamente, das alterações normativas impostas.

Nessa conjuntura, muitos setores, inclusive a academia, passaram a estudar as novidades do arcabouço jurídico e denunciar suas consequências, sublinhando a vocação do marco legal de aumentar a concentração de terras e agravar problemas ambientais, movimento esse que permaneceu com a conversão da MP na Lei 13.465/17.

Nesse sentido, evidenciou-se a relevância de aprofundar as discussões que tocam a reforma agrária, inclusive traçando necessário paralelo entre as políticas voltadas para o campo e suas repercussões nos demais setores da sociedade, para que pudesse ser percebido com maior certeza as origens do atual modelo e o agravamento dessas condições com o advento da nova lei.

Vale ressaltar, ainda, a urgência de travar o debate sobre as questões rurais nos espaços tidos como eminentemente urbanos, como o caso do Rio de Janeiro. Não obstante a estreita relação entre a produção na terra e alimentação na cidade, bem como a concentração de terras e o consequente inchaço urbano, os temas reconhecidos enquanto agrários parecem não ganhar, na atualidade, interesse nas universidades de grandes centros urbanos ou de setores da sociedade.

Portanto, é na percepção da necessidade de reflexão sobre os desafios pertinentes ao quadro de concentração fundiária e de desigualdade social, assim como a possibilidade de agravamento dessas condições com as novas 
regras de regularização fundiária, que se dá a escolha pela realização do presente trabalho.

Centrando-se na ideia de que, para melhor compreensão do caminho que se descortina com o advento da Lei 13.465/17, é relevante entender como se formou a trilha que nos levou até aqui, investigando os elementos que compõem as diversas ideias sobre reforma agrária, sua inserção nos debates dos diferentes momentos políticos e, por conseguinte, seus reflexos nas legislações pertinentes.

Nessa esteira, a análise inicia-se traçando um histórico de debates sobre reforma agrária, buscando refletir sobre os diferentes contextos de compreensão de significado da terra usando como referência os marcos da Ditadura Militar e suas normativas, seguindo para o processo constituinte e o resultado no texto constitucional e culminando no quadro atual e seus desafios.

O capítulo seguinte contém o cerne das alterações trazidas pela nova lei, sublinhando os pontos mais significativos pertinentes à reforma agrária. Após apresentar a conjuntura política que acondicionou o advento do novo marco legal, passou-se a tramitação do mesmo.

Em seguida, foram analisadas as mudanças no critério para consolidação dos projetos de assentamento e a conclusão de investimentos, as alterações na forma de titulação dos lotes dos beneficiários do Programa Nacional de Reforma Agrária, o advento da possibilidade dos assentados firmarem contratos de integração, a municipalização do processo de escolha dos beneficiários em um novo projeto de assentamento, assim como a modificação de sua ordem de preferência e a compra e venda de imóveis para fins de reforma agrária. Por fim, examinou-se a Ação Direta de Inconstitucionalidade ajuizada pela Procuradoria Geral da República em face da lei (ADI 5771).

Assim, espera-se contribuir com o debate sobre as diferentes perspectivas de relação com a terra, o campo e a reforma agrária, aprofundados com os desafios que acompanham o advento da Lei 13.465/17. 


\section{A noção de reforma agrária e seus marcos normativos no Brasil}

Com a publicação da Lei 13.465/2017, muitas críticas e reflexões entraram em campo, especialmente, no que toca a temática diretamente relacionada com a reforma agrária, sobre mudanças na consolidação dos Projetos de Assentamentos da Reforma Agrária, as diferentes formas de titulação dos lotes dos beneficiários, a inclusão da possibilidade de realização de contratos de integração em lotes e a alteração na ordem de classificação de beneficiários do Programa Nacional de Reforma Agrária, em conjunto com a municipalização do procedimento de seleção de beneficiários a serem assentados.

Grande parte do debate tem especial relação com diferentes noções do significado político da "terra", cuja caracterização enquanto mercadoria restou ainda mais evidente com o advento da nova lei. Nessa toada, muitos pesquisadores reconheceram nas alterações impostas diversos mecanismos que acarretam na recolocação no mercado de terras públicas e destinadas a reforma agrária, gerando a reconcentração de terras.

Nesse sentido, antes de ingressar em uma análise mais aprofundada sobre os aspectos da nova lei que contribuem diretamente com a chamada "contrarreforma agrária", entendendo que as mudanças normativas caminham no sentido contrário ao que o objetivo constitucional deveria promover, mostra-se extremamente relevante tecer uma reflexão sobre o arcabouço que acompanha a noção constitucional de reforma agrária, demonstrando que a conquista da terra não é personagem solitário nos elementos que constituem a noção do projeto em debate. 


\subsection{A modernização conservadora e o advento da "empresa rural": reforma agrária na Ditadura Militar}

No período anterior ao golpe militar, na madrugada do dia 31 de março de 1964, dias após a assinatura por João Goulart do decreto que declarava de interesse social para fins de desapropriação áreas rurais que ladeavam rodovias federais, ferrovias nacionais e terras beneficiadas por obras da União e que estivessem inexploradas ou exploradas contrariamente à função social da propriedade, a discussão tocante à reforma agrária configurava-se parte de um forte contraponto de ideais, uma dicotomia latente entre os movimentos considerados de esquerda e os de direita, principalmente no contexto de Guerra Fria.

Ainda nos anos anteriores ao golpe, diferentes propostas para o desenvolvimento do país eram colocadas em jogo, entre elas uma visão eminentemente técnica, que via o campo enquanto local de atraso, de resistência às modernidades necessárias ao progresso do país.

Em especial entre os anos de 1945 e os anos iniciais do governo militar, a questão agrária passou a ser desenhada enquanto óbice ao desenvolvimento, tendo em vista os baixos índices de produtividade agrícola, a recorrência das crises de abastecimento e a estreiteza do mercado de insumos. A partir de então o tema passa-se a se colocar enquanto questão nacional, posicionando-se ao lado da soberania na luta contra o atraso. É o que demonstra citação de Linhares e Silva (1999, p. 126):

\footnotetext{
aceleração de um modelo fordista-keynesiano periférico, a chamada substituição de importações, criando-se ilhas de desenvolvimento (em especial no eixo Rio/São Paulo) de relativo bem-estar social, com a concessão de benefícios sociais para grupos inicialmente restritos, como os trabalhadores industriais urbanos, a manutenção dos baixos índices de produtividade agrícola, a recorrência das crises de abastecimento e a estreiteza do mercado de insumos -fatos recorrentes nas décadas de 1950 e 1960. A questão agrária é identificada como a questão nacional, com a luta contra o atraso e pela soberania.
}

Nessa toada, a estratégia militar fixa como grande objetivo o incremento da produtividade, apostando na modernização tecnológica e 
reorganização da produção em grandes cooperativas capitalistas ou complexos agroindustriais, os chamados CAIs, constituindo a hegemonia do chamado agro-business sobre o campo. Era o momento inicial de grande incentivo a completa industrialização do campo (Linhares \& Silva, 1999, p. 126).

Assim, o projeto de modernização conservadora, marcou a nova paisagem rural brasileira, festejada ainda contemporaneamente no país ${ }^{1}$. Esse novo cenário apresentava-se em conjunto com outra estratégia basilar nas escolhas militares para lidar com a questão agrária que despontou no país, qual seja, a lógica de "ocupação de espaços vazios"2.

É nessa conjuntura, embebido nos ideais de desenvolvimento industrial do campo, que se dá o advento do Estatuto da Terra (Lei nº 4.504, de 30 ne novembro de 1964), marco legal que apontava, mesmo que deficitariamente, como veremos em seguida, critérios, instrumentos e instituições para viabilizar a reforma agrária, sempre dentro do escopo pertinente aos objetivos específicos fixados pelo governo.

Marcado pela perspectiva militar de esvaziamento total da política no debate da questão agrária, entendendo que a reforma agrária deveria funcionar tão somente no auxílio para superação dos óbices ao

\footnotetext{
1 Um elemento marcante da manutenção e incentivo dessa narrativa que festeja o sucesso do desenvolvimento industrial do campo na figura do agronegócio é a campanha "Agro: A IndústriaRiqueza do Brasil - Agro é Tech, Agro é Pop, Agro é tudo", concebida pelas gerências de Marketing e de Comunicação da Rede Globo. A campanha vinculou em rede nacional, entre julho de 2016 e julho de 2018, vídeos de cerca de cinquenta segundos que apresentam, variando a cada quinze dias, “importantes produtos do agronegócio do nosso país". Segundo o diretor de marketing da empresa, Roberto Schmidt, o "agronegócio tem que investir na construção de sua marca junto à população em geral, a fim de criar empatia e confiança”. Fonte: Agronegócio é valorizado em campanha da Rede Globo. G1, Rio de Janeiro, 01 de out. de 2016. Disponível em: 〈http://glo.bo/2dO7BRA〉. Acesso em: 15 nov. 2018; Agronegócio tem que mostrar à sociedade a tecnologia usada no campo. Universoagro, Barueri, 31 mar. 2017. Disponível em: <https://bit.ly/2PGL6S4 >. Acesso em: 19 nov. 2018.

2 Nesse ponto, vale explicitar a concepção de Martins (1984, p.41), a respeito do projeto de ocupação dos denominados "espaços vazios" na região amazônica: "Já a partir do governo Costa e Silva, o problema da terra, e particularmente da terra na Amazônia, transformou-se progressivamente num problema militar. O Ministério do Interior, ocupado pelo general Albuquerque Lima, um general nacionalista identificado com o pensamento da Escola Superior de Guerra, definiu como objetivo nacional prioritário a política de integração da Amazônia. Reduzindo a questão a termos simples, os problemas de pressão social e fundiária do Nordeste poderiam ser resolvidos na Amazônia, mediante o desenvolvimento de projetos de ocupação dos "espaços vazios", criação de polos de desenvolvimento, com envolvimento decisivo das Forças Armadas".
} 
desenvolvimento projetado pelo governo, as soluções e institutos emergidos pela lei posicionam a condução da reforma como problema técnico e militar, não como problema político (Martins, 1984, p.32).

Nesse sentido, conforme defendido por Martins (1984, p. 32), desenha-se um:

espaço limitado que o autoritarismo dos governos militares concebeu para situar as lutas camponesas e conduzir a questão agrária. Nesse espaço desenvolvem-se dois processos: a expansão da empresa capitalista no campo e o esvaziamento político do campo.

Em vista do objetivo de realizar o desenvolvimento do campo brasileiro a partir da instalação das chamadas empresas rurais, é inegável que o "destinatário privilegiado" do Estatuto da Terra é o empresário, "o produtor dotado de espírito capitalista, que organiza a sua atividade econômica segundo os critérios da racionalidade do capital" (Martins, 1984, p. 32).

Menos de dois anos depois da aprovação do Estatuto da Terra, há o sancionamento de outras duas normas que evidenciam as bases da opção militar no manejo da grave questão agrária que desafiava o país. Em conjunto com o Estatuto, formavam o arcabouço jurídico que, por um lado, indicava a positivação de institutos que propiciavam um solo mais fértil para concretização da reforma agrária, e, por outro, incendiavam os conflitos no campo.

A primeira foi a Emenda Constitucional de $\mathrm{n}^{\circ} 18$, que tratava de concessão de incentivos fiscais e favores creditícios na região da Amazônia, prática já adotada no Nordeste com o incontestável objetivo de promover a atividade agropecuária daquela faixa. É justamente nessa conjuntura que é criada a Superintendência do Desenvolvimento da Amazônia (SUDAM) (Martins, 1984, p. 34).

Em setembro de 1996, foi a vez da instituição de incentivos fiscais para empreendimentos florestais em todo o país, demonstrando que a política econômica adotada se apoiava em um robusto estímulo às ocupações de terra pelo grande capital, o que construía as duas pontes essenciais do projeto de 
desenvolvimento conservador que orientava a política agrária nos governos militares: a instalação e proliferação das empresas rurais e a ocupação dos “espaços vazios" (Martins, 1984, p. 42).

Nessa toada, não se pode perder de vista que a principal orientação do Estatuto da Terra, conforme mencionado supra, é o desenvolvimento capitalista do campo, calcado no amplo incentivo a proliferação de tais empreendimentos em áreas consideradas estratégicas pelo governo militar.

Ocorre que, na tentativa de aplacar conflitos fundiários em áreas de tensão grave, havia o reassentamento de minifundiários ou vítimas de conflitos em outras regiões, em especial as chamadas pioneiras. Nas palavras de Martins (1984, p. 33): "a reforma agrária ficou, portanto, circunscrita aos casos de tensão social grave, em áreas prioritárias".

Sem dúvidas, porém, como se verá adiante, a adoção de políticas essencialmente ambíguas, acabou por desencadear uma multiplicação dos conflitos fundiários.

Não se pode perder de vista, no entanto, que todo o projeto de reforma tinha na empresa rural seu personagem principal, focando no desenvolvimento capitalista do campo. Portanto, o escopo da reforma estava subordinado ao processo de reprodução ampliada do capital da grande empresa (Martins, 1984, p. 35).

Noutro giro, uma das principais preocupações da administração pública pós-golpe era justamente os conflitos fundiários, colocando a segurança nacional como foco primordial (Bruno, 1997, p. 183). É nesse caminhar que se situam os estudos realizados na Escola Superior de Guerra (ESG), que consideravam a paz social como premissa para o desenvolvimento do país. A abordagem técnica, em contribuição à despolitização dos debates atinentes ao campo, colocava a busca da segurança e a consolidação do novo modelo econômico como núcleo central das proposições (Bruno, 1997, p. 184). Nesse sentido, vale indicar o que levanta Bruno (1997, p. 184): 
As principais ações do governo militar visavam colocar à disposição dos produtores rurais dinheiro fácil e barato, através de mecanismos bancários e financeiros voltados para a agricultura. Atender-se-ia, desta forma, à demanda por uma agricultura mais eficiente. Era a resposta técnica à questão agrária, como a visão conservadora pretendia.

Observe-se, nessa medida, que a reforma agrária concentrava suas forças no desenvolvimento capitalista do campo, considerando que, à medida que as empresas rurais se consolidassem através da ampla facilitação creditícia, incentivos fiscais e na compra de maquinário e insumos aos grandes proprietários, o "atraso" no campo seria superado sem que houvesse a necessidade de realizar efetivamente a reforma agrária (Bruno, 1997, p. $185)$.

Sublinhando a costura focada no desenvolvimento capitalista do campo para resolução da questão agrária naquele momento, impende transcrever o resumo construído por Sérgio Leite (Apud Bruno, 1997, p. 190) das características centrais da modernização conservadora adotada no regime militar:

- $\quad$ Adoção do padrão tecnológico moderno, calcado basicamente no binômio química mineral-mecanização.

- $\quad$ Aumento da produção e da produtividade, sem o correspondente aumento da renda dos trabalhadores.

- Manutenção da estrutura fundiária, com o aumento da tendência a concentração.

- $\quad$ Expansão do crédito rural, privilegiando grandes produtores localizados na região Centro-Sul.

- Juros rurais baixos e mesmo negativos, chegando a igualar e superar o produto interno bruto do setor.

- $\quad$ Formação das CAIs, com ampla integração industrial, inclusive dos setores agropecuários.

- Integração do capital financeiro com os capitais agroindustriais e agrocomerciais.

- Transformação dos bens agrários, terra e gado principalmente, como resultado dessa integração, em poderosos ativos financeiros, homogeneizando as taxas e interesses do capital no campo e na cidade.

- Territorialização da burguesia, com investimentos maciços de grandes grupos financeiros e industriais em terras, sob a cobertura de incentivos fiscais dados pelo Estado.

- Internacionalização da agricultura brasileira, com a entrada em grande quantidade de vários itens, além do café, no comércio mundial (soja, laranja, sucos, aves, enlatados, etc.) 
É justamente nessa orientação que se encaixa o Estatuto da Terra, que, segundo Martins (1984, p. 35)

\begin{abstract}
é um instrumento de controle das tensões sociais e dos conflitos gerados por esse processo de expropriação e concentração da propriedade e do capital. É um instrumento de cerco e desativação dos conflitos, de modo a garantir o desenvolvimento econômico baseado nos incentivos à progressiva e ampla penetração do grande capital na agropecuária. É uma válvula de escape que opera quando as tensões sociais chegam ao ponto em que podem transformar-se em tensões políticas. O Estatuto está no centro da estratégia do governo para o campo e se combina com outras medidas de cerco e desativação dos conflitos, das reivindicações e das lutas sociais
\end{abstract}

Todavia, se, por um lado, havia uma forte repressão aos movimentos sociais no campo, por outro, a mesma administração fechava os olhos para a formação de grupos de jagunços, permitindo que os camponeses ficassem reféns de forças privadas de grandes proprietários e o espaço agrário se aprofundasse enquanto espaço sem lei, sem Estado, sob o jugo dos latifundiários (Bruno, 1997, p. 187).

Nesse sentido, complementa Bruno (1997, p. 188): “Tratava-se, além de dar um salto no padrão agrário vigente, de esvaziar a luta pela terra como tema nacional. Assim, a modernização, e não o conflito de classes, deveria superar o atraso".

É nesse contexto de esvaziamento político do campo, fixando a gestão da questão agrária como desafio técnico e colocando como objetivo primordial a segurança nacional, que se insere a forte repressão política no meio rural ao longo dos chamados "anos de chumbo", aliada a uma inegável postura apática para os desmandos dos grandes proprietários através de seus "jagunços", mantendo-se o que Martins caracterizou enquanto "velha realidade sertaneja, da subordinação da ordem pública pela ordem privada" (Martins, 1984, p. 38-39).

Nesse sentido, assenta Martins que a despolitização da questão fundiária foi ponto que permaneceu intocado ao longo do governo militar: 
Apesar das variações da política governamental em torno do tema da questão agrária, ao longo destes 18 anos de governo militar, esse ponto doutrinário permanece intocado: a despolitização da questão fundiária e a exclusão política do campesinato das decisões sobre os seus próprios interesses, que redundam basicamente em restrições severas à cidadania dos trabalhadores do campo. Além, é claro, do banimento da atividade política do campo, sobretudo a dos grupos populares e de oposição que assumem como corretas as lutas camponesas.

Como mencionado anteriormente, era também tônica do governo militar a lógica de "ocupação dos espaços vazios". Buscava-se "colonizar" as áreas consideradas improdutivas e não ocupadas, a partir do fomento da instalação das empresas rurais principalmente na região norte do país. O projeto, porém, não previu a explosão de conflitos rurais que começaram a se instaurar nas áreas que, afinal, já eram ocupadas por populações tradicionais e camponeses.

O resultado, como demonstra o Relatório Final da Comissão Camponesa da $\operatorname{Verdade}^{3}$, foi um aprofundamento do cerceio da condição de cidadania dos camponeses como sujeitos de direito até o ponto da supressão de seus direitos, com assassinatos, desaparecimentos forçados, ocultação de cadáveres:

No pré-golpe, entre 1946 e 1964, o regime democrático não assegurava os direitos de cidadania aos camponeses e reprimia suas lutas e organizações. Entre 1964 e 1985, a ditadura civil-militar suprimiu as liberdades democráticas de camponeses que foram perseguidos, agredidos, torturados e mortos. A mesma coisa aconteceu com advogados, religiosos e jornalistas que apoiaram a luta camponesa. Mesmo no período pós-golpe, o Estado democrático de direitos, entre 1985 e 1988, manteve políticas permissivas de violação de direitos humanos no campo.

Nesse contexto, é preciso desde logo sublinhar a discrepância nas estatísticas relativas às violações de direitos humanos no campo durante o 
regime militar. Os números colhidos pela sociedade civil chegam a ser setenta vezes maiores do que aqueles registrados pelos dados oficiais ${ }^{4}$.

O livro Camponeses Mortos e Desaparecidos: excluídos da justiça de transição, elaborado pela Secretaria de Direitos Humanos/Presidência da República ${ }^{5}$, aponta que $97,6 \%$ dos camponeses mortos e desaparecidos no período foram alijados da justiça de transição.

Segundo o estudo, ao menos 1.196 pessoas foram mortas ou desaparecidas no campo, dentre camponeses e apoiadores, desde o período pré-ditadura até o final do período de transição para a democracia.

Assim, observa-se que, como dito, muito embora tenha criado um arcabouço inicial para implementação, pelo menos em parte, do ideal de reforma agrária, o saldo do Estatuto da Terra, fundado no objetivo de modernização conservadora do campo, apresentou um braço amigo aos empresários rurais e o outro repressor e omisso quanto a aplicação das normas de distribuição de terras no país:

\begin{abstract}
Assim, por meio de incentivos fiscais para projetos agropecuários e crédito farto e barato, promoveu-se a modernização tecnológica da agropecuária nas áreas de cultivos tradicionais e foi estimulada a ocupação das fronteiras pelos grandes capitais, expulsando posseiros e índios. Os trabalhadores não puderam, a partir das atomizadas, porém recorrentes ações de resistência e das denúncias da $\mathrm{CONTAG}^{6}$, fazer valer o Estatuto da Terra, quer quanto às cláusulas que previam desapropriação de áreas de conflito, quer no que se refere à regulamentação do arrendamento e parceria ${ }^{7}$
\end{abstract}

Sendo assim, a política militar de expansão da empresa capitalista no campo, em conluio com a forte repressão e esvaziamento político no meio rural e a política de colonização, gerou um aumento expressivo das tensões

4 COMISSÃO CAMPONESA DA VERDADE. Relatório final violações de direito no campo. Brasília, DF, 2014, p. 79. Disponível em: <https://bit.ly/2mSEkds>. Acesso em: 19 nov. 2018.

5 VIANA, Gilney. Camponeses mortos e desaparecidos: excluídos da justiça de transição. Brasília, Secretaria de Direitos Humanos/Presidência da República, 2011

6 A Confederação Nacional dos Trabalhadores na Agricultura (CONTAG), criada em 22 de dezembro de 1963, foi a primeira entidade sindical do campo de caráter nacional a ser reconhecida legalmente, em 31 de janeiro de 1964. Fonte: sítio CONTAG. Disponível em: <https://bit.ly/2QaTRDe>. Acesso em: 19 nov. 2018.

7 COMISSÃO CAMPONESA DA VERDADE. Relatório final violações de direito no campo. Brasília, DF, 2014, p. 62. Disponível em: <https://bit.ly/2mSEkds>. Acesso em: 19 nov. 2018. 
sociais no campo. A região nordeste do país, em 1971 e 1972, era responsável por 19.4\% dos conflitos fundiários do Brasil e passou a representar, em 1975 e 1976, 70.2\% (Martins, 1984, p. 35).

\subsection{Redemocratização e Processo Constituinte de 1987-88}

Seguindo ao momento de transição ao regime democrático, cujas nuances e tratativas da lenta e gradual abertura mereceram devido destaque em obras específicas de análise daquele momento histórico a respeito da questão agrária ${ }^{9}$, vale discorrer brevemente sobre os movimentos em disputa já no processo constituinte de 1987 e 1988.

A exploração devastadora dos trabalhadores e sua expropriação ao longo da Ditadura Militar pela chamada modernização do campo, nos moldes anteriormente apresentados, fez com que trabalhadores agrícolas, posseiros, sem-terra e pequenos e médios produtores se associassem de múltiplas formas e objetivos, com a forte influência da igreja, em especial sua ala mais progressista, capitaneada no campo pela Comissão Pastoral da Terra (CPT) (Fernandes, 2010, p. 164-165).

É justamente sob essa atuação que nascem diversas experiências de lutas pela terra que serviram de base fértil para a formação do Movimento dos Trabalhadores Rurais Sem Terra (MST) (Fernandes, 2010, p. 164-165). Com a chamada abertura lenta e gradual, inaugurando um processo descompressivo de certa suavização da censura (Pilatti, 1988, p. 13), foi possível recolocar o debate político da reforma agrária, sufocado pelo regime militar.

Ao contrário do que é amplamente defendido, o MST teve a sua criação ainda antes do $1^{\circ}$ Encontro Nacional de Sem-Terra, com a presença de mais de 1.500 delegados camponeses, em janeiro de 1984, mas já em 1979

9 Ver PILATTI, Adriano. Marchas de uma Contramarcha: Transição, UDR e Constituinte. 1988. Dissertação (Mestrado em Direito) - Pontifícia Universidade Católica do Rio de Janeiro. 
nas primeiras ocupações de terra empreendidas no Sul do país (Fernandes, 2010, p. 165).

Um momento emblemático nessa luta foi o acampamento na

Encruzilhada Natalino ${ }^{10}$, em Ronda Alta, Rio Grande do Sul, em 1981. Embora a estratégia militar fosse a de impedir a formação do movimento social naquele momento, acabou por reacender de forma mais ampla a discussão nacional sobre o tema da reforma agrária.

Sobre a costura de entidades no apoio à Reforma Agrária, vale destacar o que aponta Bernardo Fernandes (2010, p. 169):

O processo de territorialização do MST contou com o apoio de diversas entidades. A CPT foi sem dúvida a principal articulação externa na formação e na expansão do MST, por meio de seus agentes da Pastoral e dos bispos católicos ligados a essa organização ecumênica. Além da CPT, diversos sindicatos de trabalhadores rurais, algumas igrejas protestas e entidades progressistas, como a CUT, o PT, grupos de direitos humanos e centros estudantis, apoiaram a construção do MST.

10 Encruzilhada Natalino é um acampamento estrategicamente localizado num entroncamento rodoviário de importante circulação entre as maiores cidades da região, que liga Rio Grande Sul à Santa Catarina. Após inicial organização provisória, a partir de dezembro de 1980, o assentamento evoluiu poucos meses depois para uma organização social estruturada, recebendo o apoio das igrejas Católica e Luterana, sindicatos tanto rurais quanto urbanos, comissões de Direitos Humanos, políticos de partidos de oposição ao governo militar, entre outros. O marco para ensejar a intervenção militar no acampamento foi a realização de um ato público, em 25 de julho de 1981, com a presença de mais de 15 mil pessoas. Naquele momento o acampamento já contava com 600 famílias, somando cerca de 3 mil pessoas. Após o ato, iniciou-se forte intervenção militar no acampamento, culminando com a classificação da área como de segurança nacional, entre julho e agosto de 1981. Nesse contexto, foi enviado para localidade um militar especialista em "contrainsurgência", conhecido como Coronel "Curió", que já havia atuado anteriormente no Araguaia, trabalho pelo qual foi denunciado por tortura pelo MPF. Os militares instalaram suas barracas no lado oposto ao acampamento, levantando ainda barreiras para isolar o acesso ao local, impedindo a livre circulação e, ainda, a entrada de doações ou a realização de qualquer tipo de reunião. A repressão chegou ao seu auge em 10 de agosto de 1981 quando as visitas controladas foram proibidas pelo exército, impedindo os homens de sair, portanto mantendo-os presos e permitindo a saída de mulheres somente com a informação do lugar que iriam e da hora que retornariam, sob pena de serem impedidas de retornar. Tudo isso com o objetivo de convencer os ocupantes de aceitar terrenos em projetos de colonização do governo federal na Bahia, Mato Grosso, Acre ou Roraima, dentro do prazo com termo final em 31 de agosto de 1981, data que o exército retirou-se da encruzilhada, dando lugar a uma continuada repressão efetivada pelo governo do estado, momento em que houve inclusive a contaminação da água dos ocupantes com fezes de animais. A resistência, porém, venceu. Em 23 de fevereiro de 1982, a igreja católica anunciou a possibilidade de transferência dos acampados a um abrigo provisório em Ronda Alta, após 208 dias de resistência, o que ocorreu já no mês seguinte. Em setembro de 1983, o governo desapropriou cerca de 1.870 hectares de terras nos municípios de Cruz Alta, Palmeira das Missões e Ronda Alta, onde puderam ser finalmente assentadas as famílias do acampamento Natalino. 
Da vitória na Encruzilhada Natalino seguiu um acirramento das tensões no campo. Vale ressaltar a greve de boias-frias no interior de São Paulo, em maio de 1984, momento em que 150 mil trabalhadores exigiam melhores remunerações e condições de trabalho (Pilatti, 1988, p. 49).

De igual forma, conflitos pela posse de terra também se aguçavam. No primeiro semestre de 1984, foram registradas 46 mortes de trabalhadores rurais, líderes sindicais, advogados e agentes patronais (Pilatti, 1988, p. 49). No início de outubro do mesmo ano, as federações de cooperativas agrícolas foram responsáveis pela mobilização de cerca de quarenta mil agricultores para o chamado "Grito do Campo", encontro com Tancredo realizado no estágio Beira-Rio, em Porto Alegre. Somente a CONTAG, criada ainda na década de 1960, por exemplo, já reunia, em 1985, 9 milhões de associados em 2.626 sindicatos (Pilatti, 1988, p. 42).

Os movimentos criaram uma forte discussão a respeito do significado na terra, que pode ser sintetizada pela oposição entre a "terra como negócio" e a "terra como trabalho", representando as noções de terra especulativa e terra produtiva, respectivamente (Pilatti, 1988, p. 40).

Nesse sentido, vale sublinhar que a mencionada disputa entre os sistemas antagônicos não questionava, em sua maioria, a legalidade da propriedade, mas sim a sua legitimidade, colocando no centro da discussão o elemento da função social da terra (Medeiros, 2010, p. 128).

Noutro giro, se os diversos grupos oprimidos passaram a se organizar de diferentes formas, aproveitando-se de um processo descompressivo com a suavização da censura, especialmente a partir da declaração de Figueiredo, em março de 1979, de que iria fazer do país uma democracia (Pilatti, 1988, p. 25), não poderia ser diferente no lado oposto, o dos proprietários.

Um marco para essa movimentação foi a elaboração do Plano Nacional de Reforma Agrária, elaborado pelo Ministério da Reforma e Desenvolvimento Agrário (MIRAD) em conjunto com o Instituto da Colonização e Reforma Agrária (INCRA), órgão federal criado durante a 
Ditadura Militar para implementação dos ensejos positivados no Estatuto da Terra, evidenciados pelo próprio nome da instituição.

Anunciado pelo Presidente Sarney, em 1985, no IV Congresso da Confederação Nacional dos Trabalhadores na Agricultura (CONTAG), seus detalhes e nuances já eram de prévio conhecimento dos grandes proprietários, para a indignação e descontentamento do setor, principalmente pela participação de entidades que consideravam radicais, como a ABRA (Associação Brasileira de Reforma Agrária), CPT e a própria CONTAG (Pilatti, 1988, p. 54-55).

O plano caiu como a gota d'água aos ruralistas, já descontentes com a escolha de Nelson Ribeiro, bem-visto aos olhos do clero progressista, como Ministro da Reforma e Desenvolvimento Agrário, assim como a indicação de José Gomes da Silva para a presidência do INCRA, fazendeiro e agrônomo que auxiliou na redação do Estatuto da Terra e coordenou tentativa, sem sucesso, de realização da reforma agrária em São Paulo, na ocasião de ocupar o cargo de Secretário de Agricultura do referido governo (Pilatti, 1988, p. 55).

Assim, um mês depois, era realizado o "Congresso Brasileiro da Reforma Agrária", congregando a Confederação Nacional da Agricultura (CNA), federações estaduais, Sociedade Nacional de Agricultura (SNA) e Sociedade Rural Brasileira (SRB), momento em que se autoaclamando como "produtores rurais", os presentes rechaçavam a proposta elaborada pelo MIRAD e INCRA, pedindo tempo para elaborar projeto alternativo (Pilatti, 1988, p. 61).

Toda essa multiplicidade de movimentos, forças e pressões sobre os diferentes tipos de desenvolvimento que se buscava para o campo, assim como o tom e sentido das políticas que seriam tomadas a partir da redemocratização, formavam um caldeirão de diferentes propostas e missões no período constituinte, especialmente no capítulo tocante a reforma agrária. Tanto os movimentos sociais apoiadores da reforma agrária, quanto os ruralistas, capitaneados pela União Democrática Ruralista (UDR), 
organizaram-se em torno do objetivo da cristalização de seus pontos de vista no texto constitucional.

Não é por acaso, nesse sentido, que o primeiro projeto elaborado por Bernardo Cabral, relator da Comissão de Sistematização na constituinte de 1987 e 1988, foi apelidado de "Frankenstein" (Pilatti, 2008, p. 151).

O projeto do relator era a demonstração de uma constituinte marcada por disputas de diversos setores e da influência da sociedade civil organizada, onde, em cada momento, um setor conseguia uma vitória momentânea, mas perdia no passo seguinte. A Comissão VI, intitulada Ordem Econômica, e sua subcomissão VI-C (Subcomissão da Política Agrícola e Fundiária e da Reforma Agrária) são o centro da presente análise de conjuntura da Constituinte de 1987-88.

Eram os principais atores de influência dos constituintes da subcomissão o MIRAD, o INCRA, a Conferência Nacional dos Bispos do Brasil (CNBB) e a UDR.

Os setores progressistas buscavam positivar um objetivo comum pela implementação urgente da Reforma Agrária, depois de um período de concentração fundiária crescente e de muita violência no campo no governo militar. Como sublinhado supra, era fundamental que a constituição traduzisse uma efetiva busca por transformação após o período de transição.

Do outro lado, os conservadores buscavam a garantia da propriedade privada com o mínimo de restrições possível, na tentativa de impossibilitar as desapropriações para fins de reforma agrária, especialmente com a garantia de que a propriedade produtiva não iria se sujeitar à desapropriação (Pilatti, 2008, p. 96).

Do início dos trabalhos da Constituinte até aprovação do texto constitucional muitas mudanças foram feitas, sendo os debates focados: no prazo para imissão da posse da União; na subordinação do direito de propriedade ao cumprimento de sua função ou obrigação social; na fixação de um limite máximo de área para a propriedade; no pagamento de indenização em dinheiro ou títulos de dívida pública; na possibilidade de 
desapropriação de propriedade produtiva, se descumpridos os outros requisitos da função social (Pilatti, 2008, p. 95).

Todos esses desvios, destaques e manobras só foram possíveis por conta do forte lobby organizado pela União Democrática Ruralista. Sob a liderança de Ronaldo Caiado, a entidade surgiu para buscar a concentração de forças de proprietários contra a reforma agrária e agia em diversas frentes buscando recursos através de leilões e de doações dos membros (Pilatti, 1988, p. 72). Do núcleo inicial formado por pecuaristas do eixo Goiás, São Paulo e Minas Gerais, somaram-se os grandes proprietários e empresários rurais e médios e pequenos proprietários (Pilatti, 1988, p. 67-68). Inicialmente visava-se a retirada do instrumental jurídico que permitia as desapropriações em conjunto com uma política de assessoria jurídica de prevenção e de defesa nas ações de desapropriação. A partir do início da instalação da constituinte, buscou-se uma criação de um lobby bem organizado e fiel para garantir que a defesa da propriedade fosse sagrada na Constituição que estaria por vir (Pilatti, 1988, p. 75).

Do outro lado estava a $\mathrm{CNBB}$, além e em conjunto com os demais movimentos sociais destacados anteriormente, radicalmente contrária a concentração fundiária e apoiadora de um projeto de agricultura familiar em pequenas e médias propriedades para o país. Em 1986, enquanto a UDR crescia e começava a aparecer constantemente na imprensa, a CNBB divulgou a declaração pastoral com recomendações para a constituinte, "Por uma Nova Ordem Constitucional", dando importante destaque para a urgência da Reforma Agrária. A CNBB também foi uma das maiores responsáveis pela denúncia dos assassinatos e violência no campo, acusando, inclusive, a UDR de organizar milícias para reprimir militantes sem-terra.

Um terceiro personagem é o próprio Estado em transição, que ora acenava para a possibilidade de implementação da Reforma Agrária, ora demonstrava recuo. No final, porém, o que se mostrou foi a repetição da escolha histórica pela concentração fundiária e repressão no campo em um governo que não chegou nem perto de cumprir as metas por ele programadas. 
Vale frisar, nessa toada, que no primeiro governo de transição criouse o Ministério da Reforma Agrária e Desenvolvimento (MIRAD) com Nelson Ribeiro da Silva como ministro: o primeiro aceno para a possibilidade da Reforma Agrária, uma vez que o ministro era bem visto dentre os setores progressistas, como mencionado anteriormente (Pilatti, 1988, p. 54).

Ademais, como destacado anteriormente, a equipe MIRAD e INCRA elaborou a proposta do governo para Reforma Agrária no I Plano Nacional de Reforma Agrária (PNRA) com meta de assentamento de 1,4 milhão de famílias até 1989, criados a partir de desapropriação por interesse social. A reação dos latifundiários e imprensa foi raivosa, taxando o programa de "comunista" e refutando a proposta por não contar com o setor ruralista em sua elaboração. Do outro lado, o apoio da esquerda não foi como o esperado, uma vez que consideraram a proposta "tímida e insuficiente" (Pilatti, 1988, p. 60-61).

Assim, houve o primeiro recuo do Governo Sarney, com elaboração de propostas alternativas pelo Conselho de Segurança Nacional um novo plano, sucessivas prorrogações de prazo e nove alterações, o que se demonstrou extremamente positivo para os ruralistas (Pilatti, 1988, p. 62-63).

Chegada a campanha eleitoral de 1986, que definiria os Constituintes, uma vez que a Assembleia Nacional Constituinte seria congressual, foi dada a largada aos diversos setores na tentativa de eleger candidatos que as apoiassem. Muito se fala da característica silenciosa dessas eleições, uma vez que pouco se falou de temas constitucionais de fato, mas foi marcada pela concordância ou não com o Plano Cruzado (Pilatti, 1988, p. 102).

A UDR, enquanto entidade ainda polêmica e pouco fundamentada como legítima representante dos interesses ruralistas, utilizou a "tática do silêncio" e não apoiou publicamente nenhum candidato (Pilatti, 1988, p. 116). No entanto, após as eleições, o líder Caiado afirmou que a classe estava muito bem representada (Pilatti, 1988, p. 117). Nesse meio tempo, constatouse que o Governo Sarney havia cumprido apenas 30\% das metas de desapropriação e $1,3 \%$ das metas de assentamento por ele mesmo fixadas. 
Eram maus dias para os setores progressistas de apoio à Reforma Agrária, ao final das eleições de novembro de 1986, os partidos de esquerda somados aos progressistas do PMDB não atingiam 30\% do total (Pilatti, 1988, p. 119).

Uma evidente demonstração da organização da entidade no sentido de eleger cada vez mais representantes diretos de seus interesses se dá com a entrevista de Ronaldo Caiado ao programa Roda Viva, quando, ao responder pergunta do jornalista Jorge Escosteguy sobre o grande número de representantes da agropecuária no governo ser na realidade fato histórico do nosso país, indica uma diferente noção dos objetivos da eleição, focando em candidaturas fortemente comprometidas com a classe ruralista, para além do fator básico de ser proprietário no setor agropecuário:

Então, o que a UDR tem feito é isso: é se organizar para que o voto da classe, hoje, seja para aqueles homens que realmente estarão lá no Congresso nos defendendo. Esses homens se sentirão respaldados com o nosso apoio, e nessa hora, sim, eles não serão simples produtores rurais e políticos, mas serão representantes da classe produtora rural. É esse o grande problema, nós temos que aprender a andarmos com as nossas pernas, e essa é a importância da classe estar organizada. Nós não podemos esperar que um senhor, que é presidente ou que é ministro de Estado faça tudo por nós, sendo que nós não mostramos competência em nos mobilizarmos. Essa é a necessidade de estarmos estruturados em todo país. ${ }^{11}$

Com forte presença do setor ruralista, assim como coordenada oposição progressista, os trabalhos da Subcomissão de Reforma Agrária terminaram fracassados, com a aprovação de apenas dois artigos encaminhados para a Comissão de Ordem Econômica (Pilatti, 2008, p. 104$105)$.

De início, o projeto do relator, Oswaldo Lima Filho (progressista do PMDB), era condizente com as propostas do INCRA e MIRAD: existência de uma obrigação social da propriedade, analisada através do cumprimento simultâneo de quatro requisitos, área máxima de propriedade, desapropriação

\footnotetext{
11 "O produtor rural não é vilão" diz o então presidente da UDR, afirmando também que problemas de abastecimento ocorreram em decorrência da má administração do Plano Cruzado. Memória Roda Viva, São Paulo, 6 out. 1986. Disponível em: <http://www.rodaviva.fapesp.br/imprimir.php?id=693>. Acesso em: 19 nov. 2018.
} 
com títulos de dívida pública, imissão da posse da União na fase inicial do processo judicial (Pilatti, 2008, p. 98).

A reação conservadora foi enorme, obrigando o presidente a aceitar um substitutivo apresentado por Arnaldo Rosa Prata, da ala conservadora do PMDB, com as seguintes colocações: substituição do termo obrigação por função social, sem área mínima para a propriedade, permitindo a desapropriação somente em propriedade improdutiva, pagamento em dinheiro das benfeitorias realizadas no imóvel, plena defesa do desapropriado no processo. Foram acatados pelo relator a substituição por função social da propriedade, utilizada atualmente, e a indenização em dinheiro das benfeitorias (Pilatti, 2008, p. 99-100)

Porém, o Presidente conservador do PFL, deu preferência a votação do Substitutivo Rosa Prata, considerando todo o restante prejudicado com a sua aprovação. Depois de muito tumulto e obstruções, foi aprovado o substitutivo com a possibilidade de apresentação de destaques às emendas apresentadas. Foram colocados em votação diversos destaques suprimindo os artigos $2^{\circ}$ ao $6^{\circ}$ do Substitutivo, deixando o projeto da subcomissão apenas com o $1^{\circ}$ e $7^{\circ}$ artigos.

$\mathrm{Na}$ Comissão de Ordem Econômica, a vantagem conservadora era alta entre os titulares. O relator Severo Gomes apresentou anteprojeto que, no capítulo referente a Reforma Agrária, acolhia o anteprojeto do relator da subcomissão, Oswaldo Lima Filho, a ser votado no dia 11 de junho. Na véspera da votação, havia cerva de 1500 proprietários da UDR e 1200 trabalhadores convocados pela CONTAG. O processo na comissão, porém, não foi diferente da subcomissão. Uma vez apresentado o substitutivo da UDR, também acolhendo o Substitutivo Rosa Prata, foi aprovada a prioridade de sua votação, sendo posteriormente aprovado com a retirada dos progressistas em protesto da plenária.

Restava a Comissão de Sistematização. Buscando a manutenção de suas conquistas e pressionando o relator e demais constituintes a garantirem 
as propostas ruralistas, foi organizada pela UDR a maior manifestação já ocorrida até então em Brasília.

A Marcha sobre Brasília reuniu entre 30 e 40 mil manifestantes no dia 10 de julho de 1987, a caminhada cívica também representava um interesse de união entre os empresários do campo e da cidade. Participaram os constituintes Virgílio Galassi (PDS-MG) e o já citado Rosa Prata (PMDB$\mathrm{MG})$.

A reação da Comissão de Sistematização foi o lançamento de uma proposta conciliatória, com o substitutivo da mesa elaborado pelo relator, “Cabral I". Mesmo a partir de sugestão de Virgílio Távora, porém a partir do texto de Severo Gomes (progressista relator da Comissão Temática), a UDR, com reconhecimento e legitimidade recém-conquistados, classificou o texto como “AI-5 do Campo" por conta da imissão automática da União na posse após 90 dias do decreto. Após o sucesso da manifestação, Caiado e os demais membros da UDR só aceitariam o melhor dos mundos para os ruralistas.

Na Comissão de Sistematização, porém, havia uma força progressista não vista na Comissão VI e na Subcomissão VI-C, onde os conservadores representavam importante maioria. Com a aprovação de medidas consideradas progressistas no segundo substitutivo do relator, "Cabral II", os conservadores buscaram o caminho de uma reforma regimental para alterar o texto da Comissão de Sistematização. Foi o momento ideal para a articulação de uma Frente Nacional da Livre Iniciativa, composta pela UDR, a Federação Brasileira de Bancos, a Confederação Nacional do Comércio, entre outas entidades. Dentro da constituinte também houve importante articulação conservadora, o chamado Centrão, com conservadores do PMDB, PFL, PDS, PDC, PTB e PL, apoiados pelo empresariado e o Palácio do Planalto.

As articulações foram imbatíveis: o Regimento Interno foi alterado de modo a dar força para a maioria conservadora na Assembleia Nacional Constituinte e neutralizar os avanços da ala progressista na Comissão de Sistematização. O maior problema das alterações, porém, se situava na 
possibilidade de criação de um "buraco negro", caso fossem rejeitados tanto o anteprojeto da mesa quanto os substitutivos apresentados.

No momento de decidir os artigos referentes da desapropriação para fins de reforma agrária e função social da propriedade foi exatamente o que aconteceu.

A estratégia foi a de gerar propositalmente um buraco negro para que o relator pudesse apresentar novo projeto conciliatório. Foi aberta, ainda, a possibilidade de apresentação de emendas ao novo projeto, questão que gerou debates acalorados na Assembleia. Foi aprovado o projeto de resolução do buraco negro e posteriormente aprovada uma emenda que retirava a possibilidade de desapropriação de terras produtivas, gerando um final vitorioso aos conservadores.

\subsection{A reforma agrária na Constituição de 1988}

Mesmo com a resistência na definição de função social da propriedade, a Constituição Federal de 1988 manteve esse elemento fundamental ao estudo do direito à propriedade, existente expressamente desde a Constituição de 1946.

A partir daquele momento não seria a propriedade considerada um direito fundamental absoluto ou natural, mas vinculado à ideia do cumprimento de sua função social (Silva, 2014, p. 272-273). Nesse sentido:

Se é assim, então a propriedade privada, que, ademais, tem que atender a sua função social, fica vinculada à consecução daquele princípio. É claro que, também, não é sem consequência o fato de estar inserida, no seu aspecto geral, entre as normas de previsão dos direitos individuais. É que, previsto como tal, fica assegurada a instituição, não mais, porém, na extensão que o individualismo reconheceu.

Há, portanto, o direito fundamental à propriedade em cumprimento de sua função social, conforme o Artigo 5, XXII ("é garantido o direito de propriedade”) e XXIII (“a propriedade atenderá à sua função social”). O 
mesmo entendimento fica claro com a leitura do artigo $170 \mathrm{da} \mathrm{CF} / 88$, ao incluir não só a propriedade (inciso II) como também o cumprimento de sua função social (inciso III) como princípios da ordem econômica brasileira. Não restam dúvidas, portanto, quanto a vinculação do direito de propriedade ao cumprimento de sua função social.

Todavia, o grande embate em torno da regulamentação da reforma agrária no Brasil gerou um texto constitucional controverso e ambíguo. Enquanto o artigo 186 define os requisitos para cumprimento da função social como simultâneos, o artigo anterior torna insuscetível de desapropriação para fins de reforma agrária as propriedades produtivas, apenas um dos requisitos citados no artigo seguinte.

O artigo 186 da Constituição Federal define como requisitos simultâneos para o cumprimento da função social da propriedade: "Iaproveitamento racional e adequado; II- utilização adequada dos recursos naturais disponíveis e preservação do meio ambiente; III- observância das disposições que regulam as relações de trabalho; IV - exploração que favoreça o bem-estar dos proprietários e dos trabalhadores."

O caput do referido artigo não deixa dúvidas quanto à necessidade de cumprimento simultâneo dos requisitos determinados, mas, por conta da proibição de desapropriação de terras produtivas (art. 185, II), passou a ser a produtividade o único elemento observado na análise da função social, tanto pela jurisprudência quanto pelo INCRA. Nesse sentido, haveria, na prática, uma desconstrução da ideia de simultaneidade dos requisitos, bastando apenas a verificação de um deles, o aproveitamento racional e adequado da propriedade.

Para suprir essa dúvida, Eros Grau faz uso da interpretação sistemática da Constituição Federal, deixando claro que Constituição deve ser lida e interpretada como um conjunto completo, sendo impossível analisar uma parte sem a outra. É nesse sentido que se coloca seu célebre posicionamento, 
estampado em seu voto na $\mathrm{ADPF} \mathrm{n}^{\mathrm{o}} 144 / \mathrm{DF}^{12}$ e reiteradamente citada em artigos acadêmicos sobre o tema:

(...) e tenho insistido quase excessivamente nisto, porque não se interpreta a Constituição em tiras, aos pedaços, mas sim na sua totalidade. Uma porção dela não prevalece sobre a outra quando a interpretamos. A lógica da Constituição é incindível.

Sobre a interpretação sistemática, cabe utilizar a elucidação feita por Adrian Sgarbi em sua Introdução à Teoria do Direito (Sgarbi, 2013, p. 271). Utilizando-se dessa técnica o intérprete deve buscar não as informações óbvias e literais do instrumento normativo como elemento isolado, mas observar todas as disposições do ordenamento de modo a buscar harmonia entre elas.

Não faria sentido, portanto, considerar que, a proibição feita pelo artigo 185, inciso II, fez cair por terra todo o instituto da função social da propriedade e a necessidade de leitura simultânea de seus requisitos. É necessário, por conseguinte, compreender a produtividade somente como um dos elementos para aferição de cumprimento da função social da propriedade.

Compreendendo a função social como elemento formador do conceito de propriedade e garantidor desse direito fundamental, assim como um princípio da ordem econômica brasileira, entende-se que os requisitos da função social devem ser avaliados como um todo, buscando a verificação do cumprimento de cada um deles, independentemente da produtividade.

Em suma, o momento da redemocratização e constituinte é palco de grandes disputas sobre os termos e os alcances da política de reforma agrária a partir de então. O texto cristalizado na Constituição de 1988 revela os campos e proposições em debate, mas pode ser considerado uma vitória aos proprietários, principalmente tendo em vista as técnicas de interpretação que vem sendo utilizadas pelas entidades judiciais e administrativas, com a

\footnotetext{
${ }^{12}$ STF, ADPF n. 144/DF, Rel. Ministro Celso de Mello, Brasília, 6 ago. 2008, p. 221-222
} 
análise solitária, como dito, da produtividade do imóvel rural para fins de aferimento do cumprimento de sua função social.

O latifúndio improdutivo é visto, de todo modo, como inimigo do desenvolvimento capitalista, como opção do Constituinte de 1987/1988. A produtividade, no entanto, acaba por imunizar o proprietário, deixando de lado importante discussão sobre os termos em que tal aproveitamento econômico é efetivamente alcançado.

Não há como deixar de mencionar, finalmente, que o cumprimento da função social passa a ser importante centro das discussões acerca da reforma agrária, sendo este o elemento determinante para a desapropriação para fins de reforma agrária, motivando-a ou impedindo-a.

\subsection{Reforma agrária no Século XXI: uma conversação complexa}

Não bastasse um texto constitucional ambíguo que acaba por privilegiar o elemento da produtividade, diminuindo a importância da análise dos demais requisitos para aferição do cumprimento da função social da propriedade, alguns anos foram necessários até a edição da legislação regulamentadora.

Assim, em fevereiro de 1993, foi publicada a Lei 8.629/1993, regulamentando os dispositivos pertinentes à reforma agrária previstos na Constituição Federal, assim como, em julho do mesmo ano, a Lei Complementar 76/1993, regulamentando o procedimento contraditório especial, de rito sumário, para o processo de desapropriação de imóvel rural, por interesse social, para fins de reforma agrária. Vale ressaltar que ambos os diplomas legais foram alterados pela Lei 13.465/2017, objeto de análise no presente trabalho.

Nos anos que se seguiram, houve o advento de diversas outras normas pertinentes ao tema, em especial a Medida Provisória 2.183-56 de 2001, que, entre outras questões, foi um marco na criminalização dos movimentos 


\title{
sociais de luta pela terra, incluindo normas na Lei 8.629/1993 que previam a exclusão do Programa de Reforma Agrária daquele que foi
}

\begin{abstract}
identificado como participante direto ou indireto em conflito fundiário que se caracteriza por invasão ou esbulho de imóvel rural de domínio público ou privado em fase de processo administrativo de vistoria ou avaliação para fins de reforma agrária, ou que esteja sendo objeto de processo judicial de desapropriação em vias de imissão de posse ao ente expropriante ${ }^{13}$.
\end{abstract}

De todo modo, mesmo com o sistemático descumprimento por parte do poder público, incluindo o Poder Judiciário $^{14}$, de diversas normas previstas na mencionada legislação, o arcabouço de regulamentação da questão agrária viabilizou o desencadeamento de uma política de reforma agrária, limitada, mas possível.

Por outro lado, observa-se a persistência de um modelo agrário vinculado aos ideais inaugurados no regime militar de modernização

\footnotetext{
13 Art. 2 60 O imóvel rural de domínio público ou particular objeto de esbulho possessório ou invasão motivada por conflito agrário ou fundiário de caráter coletivo não será vistoriado, avaliado ou desapropriado nos dois anos seguintes à sua desocupação, ou no dobro desse prazo, em caso de reincidência; e deverá ser apurada a responsabilidade civil e administrativa de quem concorra com qualquer ato omissivo ou comissivo que propicie o descumprimento dessas vedações.
}

§ 7o Será excluído do Programa de Reforma Agrária do Governo Federal quem, já estando beneficiado com lote em Projeto de Assentamento, ou sendo pretendente desse benefício na condição de inscrito em processo de cadastramento e seleção de candidatos ao acesso à terra, for efetivamente identificado como participante direto ou indireto em conflito fundiário que se caracterize por invasão ou esbulho de imóvel rural de domínio público ou privado em fase de processo administrativo de vistoria ou avaliação para fins de reforma agrária, ou que esteja sendo objeto de processo judicial de desapropriação em vias de imissão de posse ao ente expropriante; e bem assim quem for efetivamente identificado como participante de invasão de prédio público, de atos de ameaça, seqüestro ou manutenção de servidores públicos e outros cidadãos em cárcere privado, ou de quaisquer outros atos de violência real ou pessoal praticados em tais situações

§ 8o A entidade, a organização, a pessoa jurídica, o movimento ou a sociedade de fato que, de qualquer forma, direta ou indiretamente, auxiliar, colaborar, incentivar, incitar, induzir ou participar de invasão de imóveis rurais ou de bens públicos, ou em conflito agrário ou fundiário de caráter coletivo, não receberá, a qualquer título, recursos públicos.

§ 9oㅡ Se, na hipótese do $\S 8^{\circ}$, a transferência ou repasse dos recursos públicos já tiverem sido autorizados, assistirá ao Poder Público o direito de retenção, bem assim o de rescisão do contrato, convênio ou instrumento similar.

14 Sobre reforma agrária e o poder judiciário ver: QUINTANS, Mariana Trotta Dallalana. A magistratura fluminense: seu olhar sobre as ocupações do MST. 2005. Dissertação (Mestrado em Direito) - Pontifícia Universidade Católica do Rio de Janeiro. 215 p. Disponível em: <http://dominiopublico.mec.gov.br/download/teste/arqs/cp077273.pdf>. Acesso em: 19 nov. 2018. 
conservadora e desenvolvimento tecnológico do campo, apoiando-se especialmente na prioridade ao agronegócio e sem mudança da estrutura agrária.

Nesse sentido, destaca Carter (2010, p. 60) que as reformas feitas no Brasil não representaram ações sólidas com o objetivo de efetivamente transformar o sistema fundiário e suas relações de poder:

As medidas de reforma agrária adotadas até o momento procuraram satisfazer exigências imediatas, neutralizar conflitos locais e, acima de tudo, evitar um confronto maior com os grandes proprietários de terra. Dessa forma, elas não representaram ações contundentes com o objetivo de transformar o sistema fundiário e suas assimetrias nas relações de poder. O efeito distributivo das políticas agrárias no Brasil, apesar de significativo em alguns municípios, tem tido um impacto mínimo sobre a estrutura agrária no país.

Ao contrário, observou-se um aprofundamento desse quadro de desigualdades, sem que houvesse clareza por parte da sociedade das consequências da adoção de uma economia do agronegócio com tendência a concentração e valorização fundiária como estratégia de acumulação capitalista, como aponta Delgado (2017, p. 18):

As evidências da hegemonia política de uma economia do agronegócio com tendência a concentração e valorização fundiária como estratégia de acumulação capitalista são claras. Em contrapartida, o enfraquecimento da reforma agrária e das teses (princípios) "desmercadorizantes" das terras que o regime fundiário constitucional propõe também o são - regras ambientais, trabalhistas e de utilização racional, no conceito da função social; e ainda os princípios normativos sobre terras étnicas (indígenas e quilombolas).

Mas não ficam claras para a sociedade, partidos políticos, movimentos sociais, opinião pública etc., as implicações políticas das inversões promovidas no regime fundiário. Tampouco se percebem na situação as consequências desestruturantes relativamente a coesão social, sustentabilidades ambiental-ecológico e de certa igualdade econômica no espaço rural.

Nessa toada, cumpre destacar os dados levantados por Alentejano (2011, p. 72), que evidenciam a persistência da desigualdade na estrutura fundiária brasileira.

Os imóveis com menos de de 10 ha são 31,6\% do total, mas ocupam apenas 1,8\% da área e os com mais de 500 ha representam apenas $0,2 \%$ do total de imóveis, mas 
controlam 13,4\% da área. Somados os imóveis com menos de 100 ha correspondem a $85,2 \%$ do total e possuem menos de $20 \%$ da área, ao passo que os que possuem mais de 100 ha são menos de $15 \%$ dos imóveis e concentram mais de $80 \%$ da terra.

O resultado dessa conjuntura de concentração de terras é observado em diversos fatores, em especial, na expulsão dos trabalhadores do campo gerando o inchaço das cidades, com todas as suas consequências, assim como no incremento da devastação ambiental (Carter, 2010, p. 60), inclusive com a facilitação da transferência do patrimônio natural brasileiro para o controle estrangeiro (Alentejano, 2011, p. 74), no aumento de conflitos fundiários (Delgado, 2017,p. 22) e na insegurança alimentar (Alentejano, 2011, p. 80).

A mencionada assimetria nas relações de poder no campo é estampada por Carter (2010, p. 62), ao revelar que embora o número de camponeses sem-terra e agricultores familiares alcance 6.120 .000 pessoas, enquanto o de grandes proprietários rurais e agronegócio seja de apenas 22.000, a representação política do mesmo grupo limita-se a 10 pessoas e o do segundo era nove vezes maior: 93 pessoas. Como consequência dessa superrepresentação e da política de valorização e incremento do agronegócio adotada historicamente no país, conforme analisado no presente, os gastos públicos voltados para o primeiro grupo entre 1995 e 2005, totalizaram o valor de 10,2 bilhões de dólares americanos, enquanto os grandes proprietários rurais e agronegócio perceberam quase seis vezes esse monte: 58,2 bilhões de dólares americanos.

Nesse sentido, vale ressaltar que, conforme será analisado no capítulo referente a conjuntura política com o advento da nova lei de regularização fundiária, a perspectiva de sub-representação orçamentária vem sendo aprofundada no país, a despeito do quadro de precariedade enfrentado pelos trabalhadores rurais.

Nesse aspecto, torna-se fundamental analisar o quadro atual dos assentamentos rurais brasileiros, utilizando como referência o estudo Impactos de Assentamentos: um estudo sobre o meio rural brasileiro (Leite et al., 2004). 
Antes de adentrar nos dados coletados pelos pesquisadores, que evidenciam a debilidade dos assentamentos rurais ao longo do país, vale destacar a importância de suas condições e estruturas que, quando não atendidos, "podem se constituir em gargalos importantes para a viabilização os projetos de assentamento e para a melhoria das condições de vida dos que neles vivem" (Leite et al., 2004, p. 86).

As investigações realizadas nos assentamentos existentes no país naquele momento, revelaram que, no que se refere ao crédito-habitação, por exemplo, 27\% das famílias ainda não haviam sido atendidas e o tempo médio para recebimento de crédito-fomento variou entre nove meses no Ceará e 12 anos no Sudeste do Pará, perfazendo uma média geral de quatro anos para sua concessão. O mesmo tempo médio foi observado para recebimento do crédito-alimentação, enquanto o crédito-habitação é percebido com tempo médio de cinco anos pelos beneficiários (Leite et al., 2004, p. 88).

Diretamente relacionados às questões de saúde dos assentados, encontram-se ainda dados que revelam que apenas $63 \%$ das casas possuem banheiros, a maioria dos assentamentos possuem lotes com problemas de falta de água ou água de má qualidade e o quadro mais comum é a inexistência de qualquer sistema de escoamento de esgoto, situação de pelo menos parte dos lotes em $80 \%$ dos assentamentos pesquisados (Leite et al., 2004, p. 90).

No que toca à rede elétrica, a prestação desse serviço é inexistente em $22 \%$ dos assentamentos, sendo que somente $27 \%$ do total dos projetos são servidos em sua totalidade. Cumpre destacar, ainda, que 53\% daqueles em que há energia, os entrevistados pelos pesquisadores afirmaram ter sido necessária reivindicação para obtê-la (Leite et al., 2004, p. 92).

Por fim, vale destacar elementos pertinentes ao trânsito de assentados e escoamento de suas produções. O asfalto até a entrada do assentamento só é presente em $20 \%$ dos casos, predominando estradas de terra (46\%) ou parte terra e parte asfalto (34\%). A inacessibilidade na época de chuvas apresentou- 
se como grave e recorrente problema, ocorrendo em $52 \%$ dos assentamentos (Leite et al., 2004, p. 94).

Mesmo nessas condições, a maior parte dos alimentos consumidos pela população brasileira é proveniente da agricultura familiar, que apresenta maior produtividade por hectare do que fazendeiros em grande escala, o que gera $87 \%$ de toda a mão de obra rural no país (Carter, 2010, p. 69).

Sendo assim, em vista dos dados e elementos discutidos no presente capítulo, evidencia-se que a reforma agrária é disparadora de uma série de outras discussões, principalmente se observadas as mencionadas consequências da concentração fundiária.

Nesse sentido, cumpre destacar a defesa de Carter (2010, p. 71) de que o debate da reforma agrária toca assuntos que se transcendem a questão fundiária e o desenvolvimento rural:

O debate em vigor no Brasil sobre a reforma agrária toca assuntos que ultrapassam a questão fundiária e o desenvolvimento rural. Os assuntos em pauta levantam sérios problemas mais profundos da sociedade brasileira. Na alvorada do século XXI, a reforma agrária continua sendo parte de uma conversação complexa e contenciosa sobre o futuro do Brasil - suas promessas e necessidades, seus temores e sonhos.

\section{Lei 13.465/17: alterações normativas e repercussões na política de reforma agrária}

\subsection{Conjuntura política e desmonte de políticas públicas}

Antes de ingressar numa análise pormenorizada das alterações trazidas pela Lei 13.465/17 e apontar os motivos pelos quais muitas críticas podem ser tecidas a esse respeito, é fundamental sublinhar a conjuntura política em que a norma se insere. Afinal, trata-se de um momento em que, como se demonstrará, foram feitas diversas movimentações na estrutura e orçamento pertinente à reforma agrária que assinalavam fortemente para os retrocessos que vieram estampados na nova regularização. 
Uma importante mudança estrutural ocorreu já no mesmo dia em que Michel Temer (MDB) se tornou presidente interino do país ${ }^{15}$, em vista da aprovação da instauração do processo de impeachment da presidenta Dilma Roussef (PT) pelo Senado Federal, em 12 de maio de $2016^{16}$.

Assim, nessa data, foi publicada a Medida Provisória $n^{\circ} 726$, que alterou e revogou Lei no 10.683, de 28 de maio de 2003, que dispõe sobre a organização da Presidência da República e dos Ministérios, reduzindo de 32 para 23 o número de Ministérios. No que toca a temática pertinente à presente análise, a norma editada já pelo presidente interino marcou a extinção do Ministério do Desenvolvimento Agrário (MDA), instituído com essa nomenclatura em janeiro de 2000. Na mesma medida, transformou ainda o Ministério do Desenvolvimento Social e Combate à Fome em Ministério do Desenvolvimento Social e Agrário.

Aqui vale colacionar a análise de Guilherme Cassel, ex-Ministro de Desenvolvimento Agrário, que avalia tal mudança enquanto uma demonstração da perspectiva do governo Michel Temer sobre a agricultura familiar ${ }^{17}$. Segundo ele, iniciou-se nos anos anteriores uma alteração na perspectiva desse campo, entendendo-o enquanto importante agregador no desenvolvimento econômico do país, inserindo-se enquanto personagens do setor produtivo e, como tal, caracterizando as políticas que o cercam como de cunho eminentemente econômico. Todavia, o olhar evidenciado pela Medida Provisória colocaria as questões pertinentes à agricultura familiar enquanto essencialmente sociais, no que caracterizou como um sinal de que voltariam a ser "considerados como pobres improdutivos que precisam ser apoiados por política social".

\footnotetext{
1534 TALENTO, Aguirre; COLON, Leandro. Michel Temer é notificado e se torna oficialmente presidente interino. Folha de São Paulo, São Paulo, 12 mai. 2016. Seção Poder. Disponível em: <https://bit.ly/2Kh5t27>. Acesso em: 19 nov. 2018.

${ }^{16}$ Processo de Impeachment é aberto e Dilma é afastada por até 180 dias. G1, Rio de Janeiro, 12 mai. 2016. Seção Política. Disponível em: 〈http://glo.bo/1ZIdjlE〉. Acesso em: 19 nov. 2018.

17 WEISSHEIMER, Marco. "Um dos objetos do golpe é quebrar a agricultura familiar", diz Guilherme Cassel. Brasil de Fato, São Paulo, 21 jun. 2017. Disponível em: <https://bit.ly/2Khr76C>. Acesso em: 19 nov. 2018.
} 
Outrossim, ainda no final do mês de maio, adveio a publicação do Decreto $\mathrm{n}^{\mathbf{0}}$ 8.780, transferindo as competências do extinto Ministério do Desenvolvimento Agrário, abarcadas pelo Ministério do Desenvolvimento Social e Agrário, para a Casa Civil da Presidência da República, chefiada pelo Ministro Eliseu Padilha (MDB), pecuarista acusado pelo Ministério Público Estadual do Mato Grosso de grilagem e de diversos crimes ambientais em fazenda localizada na área no Parque Estadual Serra de Ricardo Franco, em Vila Bela da Santíssima Trindade $(521 \mathrm{~km}$ a oeste de Cuiabá), na fronteira com a Bolívia ${ }^{18}$. No mesmo diploma, houve ainda a subordinação do INCRA ao mesmo órgão.

Cumpre ressaltar que sobreveio ao mencionado diploma a publicação do Decreto $\mathrm{n}^{\mathrm{o}} 8.865$, em setembro de 2016, que revogou o anterior, porém manteve a transferência das supracitadas competências à Casa Civil e a subordinação do INCRA.

No ano seguinte, em 31 de agosto, o Congresso Nacional recebeu do Executivo o Projeto de Lei Orçamentária para 2018 (PLOA 2018) ${ }^{19}$, que seguia a linha de austeridade que incentiva importantes cortes orçamentários $^{20}$, com grande desmonte das políticas na área de estudo do presente trabalho, no que a Confederação Nacional dos Trabalhadores e Trabalhadoras na Agricultura Familiar do Brasil (Contraf Brasil) qualificou como um "definhamento de programas e até mesmo a o fim de projetos"21.

\footnotetext{
${ }^{18}$ WERNECK, Keka. Procurador acusa governo de agir a favor de ministro. Ministério Público do Estado do Mato Grosso, Mato Grosso, 27 jan. 2017. Seção MP nos Jornais. Disponível em: 〈https://bit.ly/2OSkLLF>. Acesso em: 19 nov. 2011.

${ }^{19}$ Projeto da Lei Orçamentária para 2018 chega ao Congresso. Senado Notícias, Brasília, 31 ago. 2017. Disponível em: 〈https://bit.ly/2S9C2SD>. Acesso em: 20 nov. 2018.

${ }^{20}$ KLIASS, Paulo. $O$ desmonte de Temer: O financismo pretende sufocar os serviços de saúde, educação, previdência e demais direitos republicanos que devem ser oferecidos pelo Estado brasileiro. Carta Maior, 15 jun. 2016. Disponível em: 〈https://bit.ly/2Q7eGiZ〉. Acesso em: 20 nov. 2018.

${ }^{21}$ COSTA, Patrícia. Corte no orçamento de 2018 deixa reforma agrária por um fio. CONTRAF Brasil, Brasília, 25 set. 2017. Seção Notícias. Disponível em: <http://bit.ly/2ftRECB>. Acesso em: 20 nov. 2018.
} 
A análise comparativa dos orçamentos da União pode ser feita a partir do Projeto de Lei do Congresso Nacional n ${ }^{\circ} 20$, de $2017^{22}$ em confronto com as informações fornecidas pelo Sistema Integrado de Planejamento e Orçamento (SIOP) ${ }^{23}$.

O projeto apresentou corte no orçamento no INCRA para obtenção de terra para a reforma agrária, passando de $\mathrm{R} \$ 257.023 .985$, em 2017 , para $\mathrm{R} \$$ 34.291 .986 , significando uma queda de $86,7 \%$ dos valores previstos para esse fim. No que toca ao montante destinado ao desenvolvimento de estrutura nos assentamentos verificou-se um corte de $69 \%$, saindo de $\mathrm{R} \$ 242.524 .796$ para $\mathrm{R}$ \$ 75.349.622. Quanto a quantia reservada a organização da estrutura fundiária houve corte de 89,5\%, com queda de $\mathrm{R} \$ 108.105 .000$ para $\mathrm{R} \$$ 8.092.364. Vale dizer que em 2016, no entanto, o orçamento destinado para tanto era de apenas $R \$ 27.342 .843$ e, portanto, houve aumento significativo do orçamento entre 2016 e 2017, com corte no ano seguinte.

No que toca à Secretaria Especial de Agricultura Familiar, o montante para o fortalecimento desse modelo foi reduzido em $73,7 \%$, tendo em vista a reserva de \$38.808.107 em 2017 e de apenas 10.217 .540 em 2018. O apoio ao desenvolvimento sustentável de territórios rurais caiu $77,2 \%$, partindo de $\mathrm{R} \$ 110.189 .784$ em 2017 para $\mathrm{R} \$ 25.127 .200$ no ano seguinte. A área de crédito fundiário perdeu 79,3\% de seu orçamento, haja vista a previsão de $\mathrm{R} \$$ 24.809.989 em 2017 e apenas R $\$ 5.128 .000$ em 2018. Por fim, cabe ressaltar o corte de $86,1 \%$ no orçamento para promoção da educação no campo, passando de $\mathrm{R} \$ 14.800 .000$ para $\mathrm{R} \$ 2.053 .682$.

Torna-se fundamental sublinhar, no entanto, que a diminuição orçamentária da quase totalidade das áreas mencionadas vem sendo implementado desde pelo menos 2015. O montante destinado à obtenção de

\footnotetext{
${ }^{22}$ Projeto de Lei do Congresso Nacional n ${ }^{\circ} 20$, de 2017. Congresso Nacional, Brasília. Disponível em: <https://bit.ly/2PFspy4>. Acesso em: 20 nov. 2018.

23 Sistema Integrado de Planejamento e Orçamento. Ministério do Planejamento, Desenvolvimento e Gestão, Brasília. Disponível em: <https://www.siop.gov.br/siop/>. Acesso em: 20 nov. 2018
} 
terra para reforma agrária, por exemplo, saiu de $\mathrm{R} \$ 800.000 .000$, em 2015 , para $\mathrm{R} \$ 333.401 .507$, em 2016, e R\$257.023.985, em 2017.

Nesse contexto, como forma de denunciar os desmontes no programa de reforma agrária, diversos movimentos sociais de luta pela terra organizaram, a partir de 16 de outubro de 2017, Dia Mundial da Alimentação, uma "jornada unitária" que foi marcada pela ocupação do Ministério do Planejamento, Desenvolvimento e Gestão ${ }^{24}$. Não foram observadas, todavia, alterações significativas no projeto do governo após as mobilizações.

É nessa conjuntura que se dá o advento da Lei 13.465/17 que, como se verá adiante, demandaria, na verdade, de incremento na previsão orçamentária, tendo em vista, em especial, a aposta na compra pelo poder público de terras para fins de reforma agrária e a consolidação célere e em massa dos projetos de assentamento.

\subsection{Tramitação no Congresso Nacional}

Em 21 de dezembro de 2016, foi enviado ao Presidente da República Michel Temer a exposição de motivos para a edição de Medida Provisória para com o objetivo de dispor "sobre regularização fundiária rural e urbana, institui mecanismos para melhor eficiência dos procedimentos de alienação de imóveis da União, dispõe sobre a liquidação de créditos concedidos aos assentados da reforma agrária, sobre a regularização fundiária no âmbito da Amazônia Legal”25.

O documento, assinado pelo Deputado Federal Bruno Cavalcanti de Araújo (PSDB/PE), então Ministro das Cidades, Dyogo Henrique de Oliveira, então Ministro Interino de Planejamento, Desenvolvimento e Gestão, e Eliseu Padilha, Ministro-chefe da Casa Civil, levantava como

\footnotetext{
${ }^{24}$ MST ocupa sede do Ministério do Planejamento em Brasília. Jornal do Brasil, Rio de Janeiro, 17 out. 2017. Disponível em: 〈https://bit.ly/2A79q4J〉. Acesso em: 20 nov. 2018.

${ }^{25}$ ARAÚJO, Bruno Cavalcanti de; OLIVEIRA, Dyogo Henrique de; PADILHA, Eliseu. EMI $n^{o}$ 00020/2016 MCidades MP CCPR. Brasília, 21 dez. 2016. Disponível em: <https://bit.ly/2x2wjqn>. Acesso em: 20 nov. 2018.
} 
fundamentos principais para as alterações propostas o direito à moradia, a vigência de diversas normas de hierarquias diferentes versando sobre regularização fundiária, inclusive de maneira contraditória, o que resultaria em um cumprimento adequado do comando constitucional cada vez mais mitigado, assim como acórdãos do Tribunal de Contas da União (TCU), como forma de embasar o requisito de urgência de que deve ser dotada a Medida Provisória, e, por último, argumentava pela necessidade de alterações pontuais na legislação própria com o objetivo de aprimorar o processo de seleção, supervisão e titulação dos beneficiários dos projetos de assentamentos de reforma agrária no país.

Nesse passo, somente no que tange ao Título I, chamado de "Dos Procedimentos de Regularização Rural e Outras Disposições”, eram propostas alterações nas seguintes normativas:

- Lei $\mathrm{n}^{\circ}$ 8.629/93, de 25 de fevereiro de 1993, que dispõe sobre a regulamentação dos dispositivos constitucionais relativos à reforma agrária;

- Lei $n^{\circ} 13.001$, de 20 de junho de 2014, que dispõe sobre a liquidação de créditos concedidos aos assentados da reforma agrária;

- Lei $\mathrm{n}^{\circ} 11.952$, de 25 de junho de 2009, que dispõe sobre a regularização fundiária no âmbito da Amazônia Legal; 9.4.

- Lei no 8.666, de 21 de junho de 1993, que regulamenta o art. 37, inciso XXI, da Constituição Federal;

- Lei $n^{\circ} 6.015$, de 31 de dezembro de 1973, que dispõe sobre os registros públicos e dá outras providências; e

- Lei $n^{\circ} 12.512$, de 14 de outubro de 2011, que dispõe sobre o Programa de Aquisição de Alimentos - PAA.

A Medida Provisória n ${ }^{0}$ 759/2016 foi então publicada no apagar das luzes do ano de 2016, em 26 de dezembro, com vigência a partir do dia 02 de fevereiro de 2017 até $1^{\circ}$ de junho de 2017. 
Já no dia 06 de fevereiro de 2017, foi instituída Comissão Mista incumbida de emitir parecer sobre a matéria, quando foram apresentadas 732 emendas à Medida Provisória.

Um mês depois, em 07 de março de 2017, foi designado como Presidente da comissão o Deputado Izalci Lucas (PSDB/DF) e Revisor Deputado Pauderney Avelino (DEM/AM), momento em que foram feitos 23 requerimentos solicitando a realização de audiências públicas. Já no final do mesmo mês, houve a designação do Senador Romero Jucá (MDB/RR) para o cargo de Relatoria, seguido de novos requerimentos para realização das mencionadas audiências, o que foi aprovado na segunda reunião da comissão, em 29 de março.

No mês de abril, foram realizadas quatro audiências públicas, culminando com a apresentação de relatório elaborado pelo Senador Romero Jucá, no dia 25.

Concedida vista coletiva ainda no final de abril, houve já no início de maio o recebimento de duas complementações de voto. No dia 03 de maio, foi aprovada a redação final do Relatório da Comissão Mista, com dezesseis votos favoráveis e quatro votos contrários, de modo que o parecer concluiu pela "constitucionalidade, juridicidade e boa técnica legislativa da Medida Provisória, bem como pelo atendimento dos pressupostos de relevância e urgência e pela sua adequação financeira e orçamentária e, no mérito, pela aprovação da Medida Provisória $\mathrm{n}^{\circ}$ 759, de 2016, na forma do projeto de lei de conversão apresentado". Foram acolhidas total ou parcialmente 42 emendas com o tema "Regularização rural em Reforma Agrária", 55 emendas sobre "Regularização rural fora da Reforma Agrária", 37 emendas que tocam a "Regularização urbana: aspectos gerais", uma emenda sobre "Regularização urbana: aspectos conexos" e, por fim, quatro emendas relacionadas a "Regularização de Bens da União: aspectos conexos"26.

\footnotetext{
${ }^{26}$ Complementação de voto ao relatório apresentado na comissão mista destinada a emitir parecer sobre a medida provisória n ${ }^{\circ}$ 759/2016. Comissão Mista da MPV no 759, de 2016. Senado Federal, Brasília. Disponível em: <https://bit.ly/2DPc1Vc>. Acesso em: 20 nov. 2018.
} 
Houve, ainda, a apresentação de um voto em separado elaborado pela Deputada Luiza Erundina (PSOL/SP) e do Deputado Edmilson Rodrigues $(\mathrm{PSOL} / \mathrm{PA})^{27}$.

O texto final da Comissão Mista, nesse sentido, concluiu pela apresentação do Projeto de Lei de Conversão no 12/2017, aprovado em discussão em turno único no plenário da Câmara dos Deputados, com relatório feito pelo Deputado Pauderney Avelino. Seguindo para o Senado, o projeto foi aprovado em 31 de maio de 2017, de onde seguiu para sanção presidencial.

Todavia, o Projeto de Lei de Conversão foi devolvido ao Senado em cumprimento à Medida Cautelar em Mandado de Segurança de no $34.907^{28}$, deferida em 19 de junho de 2017, com a relatoria do Ministro Luis Roberto Barroso, que determinou que o texto deveria retornar à apreciação da casa iniciadora, à luz do art. 65, parágrafo único, da $\mathrm{CRFB} / 88$, tendo em vista que as emendas aprovadas pelo Senado teriam ensejado alterações de mérito que obrigam seu retorno à Câmara dos Deputados antes de ser enviadas à sanção presidencial, o que não foi feito pelo Presidente do Senado, Senador Eunício de Oliveira (MDB/CE).

Sendo assim, em 27 de junho de 2017, o plenário da Câmara dos Deputados discutiu as emendas do Senado Federal ao PLV nº 12/2017, com aprovação das oito emendas propostas naquela casa. Aprovada a redação final assinada pelo Relator Deputado Pauderney Avelino, foi então o projeto novamente enviado a sanção presidencial.

No dia 11 de julho de 2017, com publicação no Diário Oficial da União no dia seguinte, sancionada pelo Presidente da República Michel Temer a Lei $13.465 / 17$.

\footnotetext{
27 Voto em separado (Da Sra. Deputada Luiza Erundina e Sr. Deputado Edmilson Rodrigues). Comissão Mista da Medida Provisória no 759, de 2016. Senado Federal, Brasília. Disponível em: <https://bit.ly/2TuIpRO>. Acesso em: 20 nov. 2018.

${ }^{28}$ STF. Medida Cautelar em Mandado de Segurança no 34.907/DF, Rel. Ministro Luís Roberto Barroso, Brasília, 19 jun. 2017.
} 
Vale ressaltar, portanto, que a Lei 13.465/17, que teve seu início com a Exposição de Motivos encaminhada ao Presidente da República em 21 de dezembro de 2016, trazendo alterações em vinte e uma leis, uma Medida Provisória, quatro Decretos-Leis e uma Lei Complementar ${ }^{29}$, foi publicada pouco mais de seis meses depois, com apenas quatro oportunidades de participação e discussão da sociedade, em contraponto à normativas criadas a partir de debates de mais de duas décadas para adequação à complexa realidade fundiária brasileira, o que foi levantado pelo Procurador Geral da República na Ação Direta de Inconstitucionalidade que tem por objeto a lei ora em análise, como será discutido adiante.

\subsection{Mudanças e inovações da Lei $13.465 / 17$}

Muito embora a Lei 13.465/17 tenha, como afirmado e reafirmado supra, alterado uma série de legislações pertinentes à regularização fundiária rural e urbana, ambiental, processo civil, entre outras, optou-se no presente trabalho por um fazer um recorte de análise dos impactos da lei na área rural e, dentro desse escopo, focar-se nas implicações especificamente no desenvolvimento da reforma agrária no Brasil.

Nesse sentido, justamente por conta da extensão e importância das alterações trazidas, mostrou-se fundamental a realização do mencionado

\footnotetext{
${ }^{29}$ Ementa Lei 13.465, de 12 de julho de 2017: “Dispõe sobre a regularização fundiária rural e urbana, sobre a liquidação de créditos concedidos aos assentados da reforma agrária e sobre a regularização fundiária no âmbito da Amazônia Legal; institui mecanismos para aprimorar a eficiência dos procedimentos de alienação de imóveis da União; altera as Leis nos 8.629, de 25 de fevereiro de 1993, 13.001, de 20 de junho de 2014, 11.952, de 25 de junho de 2009, 13.340, de 28 de setembro de 2016, 8.666, de 21 de junho de 1993, 6.015, de 31 de dezembro de 1973, 12.512, de 14 de outubro de 2011, 10.406, de 10 de janeiro de 2002 (Código Civil), 13.105, de 16 de março de 2015 (Código de Processo Civil), 11.977, de 7 de julho de 2009, 9.514, de 20 de novembro de 1997, 11.124, de 16 de junho de 2005, 6.766, de 19 de dezembro de 1979, 10.257, de 10 de julho de 2001, 12.651, de 25 de maio de 2012, 13.240, de 30 de dezembro de 2015, 9.636, de 15 de maio de 1998, 8.036, de 11 de maio de 1990, 13.139, de 26 de junho de 2015, 11.483, de 31 de maio de 2007, e a 12.712, de 30 de agosto de 2012, a Medida Provisória no 2.220, de 4 de setembro de 2001, e os Decretos-Leis nos 2.398, de 21 de dezembro de 1987, 1.876, de 15 de julho de 1981, 9.760, de 5 de setembro de 1946, e 3.365, de 21 de junho de 1941; revoga dispositivos da Lei Complementar no 76, de 6 de julho de 1993, e da Lei no 13.347, de 10 de outubro de 2016; e dá outras providências."
} 
recorte para que os assuntos pertinentes à regularização fundiária em reforma agrária pudessem ser melhor e mais profundamente abordados.

Vale mencionar que a escolha das alterações analisadas se deu a partir do contato com as maiores demandas e críticas dos movimentos sociais, entendendo os temas investigados no presente trabalho como aqueles que mais impactariam a implantação da reforma agrária, tanto no aspecto inicial, da conquista da terra, quanto no desenvolvimento dos assentamentos rurais.

\subsubsection{Critério para consolidação dos projetos de assentamento e a "conclusão de investimentos"}

Uma das principais mudanças trazidas pela lei objeto de análise do presente trabalho foi a inclusão do requisito da temporalidade para a consolidação dos projetos de assentamentos de reforma agrária, passando este a ser o elemento fundamental para considerar-se consolidado o projeto.

Conforme definição legal, à luz do $\$ 1^{\circ}$ do art. 46 do Decreto 9.311 de 15 de março de 2018, a consolidação “encerra a disponibilização pelo INCRA dos investimentos de infraestrutura”.

Sendo assim, a partir da consolidação, o instituto não será mais diretamente responsável pela condução e garantia das melhorias necessárias para a instalação e permanência dos assentados. A partir da consolidação, considera-se que o projeto já foi suficientemente desenvolvido para garantia da dignidade daquelas famílias, possibilitando, em teoria, que lá consigam habitar, plantar, ir à escola, ao posto de saúde, ter acesso a infraestrutura essencial, como saneamento básico e energia elétrica.

Nesse sentido, o inciso $\mathrm{V}$ do art. 17 da Lei 8.629/93 fixa os requisitos que devem ser alcançados para que o assentamento possa se consolidar:

Art. 17. O assentamento de trabalhadores rurais deverá ser realizado em terras economicamente úteis, de preferência na região por eles habitada, observado o seguinte: 
$\mathrm{V}$ - a consolidação dos projetos de assentamento integrantes dos programas de reforma agrária dar-se-á com a concessão de créditos de instalação e a conclusão dos investimentos, bem como com a outorga do instrumento definitivo de titulação.

Os créditos de instalação, por sua vez, passaram a ser regulamentados pelo Decreto 9.424 de 26 de junho de 2018. Noutra senda, a conclusão de investimentos é tratada pelo já mencionado Decreto 9.311 e será melhor analisada em seguida. Da mesma forma, o instrumento de titulação será alvo de investigação própria no momento pertinente.

Observa-se, nesse sentido, que o inciso transcrito prescreve três requisitos elementares para a consolidação dos projetos de assentamento: a concessão dos créditos de instalação, a conclusão de investimentos e a outorga de instrumento definitivo de titulação.

Ocorre que, com a inclusão do $\S 6^{\circ}$ ao art. 17 da Lei 8.629/93 pela Lei 13.465/17, atingido o prazo de 15 anos da implementação do projeto de assentamento, será o mesmo considerado consolidado, independentemente dos requisitos supracitados. Para os assentamentos que, em $1^{\circ}$ de junho de 2017, já atingiram o prazo fixado, foi determinado que deveriam ser consolidados em até três anos, segundo o $§ 7^{\circ}$ do mesmo artigo.

Nessa toada, vale transcrever os mencionados dispositivos:

§ 6o Independentemente da implementação dos requisitos exigidos no inciso $\mathrm{V}$ do caput deste artigo, considera-se consolidado o projeto de assentamento que atingir o prazo de quinze anos de sua implantação, salvo por decisão fundamentada do Incra.

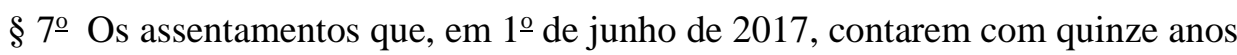
ou mais de criação, deverão ser consolidados em até três anos.

Tal alteração legislativa foi recebida com extrema preocupação por grande parte dos movimentos sociais de luta pela terra, tendo em vista que, com a consolidação, são finalmente outorgados os títulos definitivos e, havendo uma consolidação massiva de projetos de assentamento sem que os beneficiários tenham de fato condições de se estabelecer, tendo em vista que 
os requisitos para tanto não terão sido efetivamente garantidos, a tendência é que haja um retorno das terras ao mercado ${ }^{30}$.

Nesse ponto, vale destacar a morosidade normalmente observada para a concessão dos créditos de instalação, como vimos, o que aponta para a possibilidade de consolidação de projetos em situações absolutamente precárias.

Noutro giro, impende analisar a perspectiva de consolidação massiva dos assentamentos com mais de 15 anos, na forma do $\$ 7^{\circ}$ do art. 17 da Lei 8.629/93, o que Sauer descreve como um retorno à crença dominante no governo Fernando Henrique Cardoso, onde buscou-se realizar a mesma política, de que a questão agrária se resolveria com a garantia de terras para aqueles que já estavam assentados, de modo que a consolidação massiva encerraria o tema da reforma agrária (Leite \& Sauer, 2017b, p. 5). Não é preciso de muito para perceber que a estratégia não foi bem-sucedida.

No que concerne ao instituto da "conclusão de investimentos", vale transcrever o que prescreve o artigo 46 do Decreto 9.311/2018:

Art. 46. Para efeitos do disposto no inciso V do caput do art. 17 da Lei $n^{\circ}$ 8.629/93, de 1993, serão considerados:

I - conclusão dos investimentos:

a) a execução dos serviços de medição e demarcação topográfica georreferenciada do perímetro e das parcelas no projeto de assentamento, conforme critérios estabelecidos pelo Incra; e

b) a viabilização de meios de acesso no assentamento que permitam o trânsito de pessoas e o escoamento da produção e a instalação de energia elétrica, de abastecimento de água e de moradia no assentamento; e

II - concessão dos créditos de instalação - a disponibilização de créditos de instalação previstos no Decreto n $^{\circ}$ 9.066, de 31 de maio de 2017, a no mínimo cinquenta por cento dos beneficiários do assentamento.

Há de se observar, nesses termos, que a consolidação do assentamento e a conclusão de investimentos gira em torno dos diversos elementos que ensejam a garantia de dignidade e acesso aos direitos fundamentais aos

\footnotetext{
${ }^{30}$ Notas Sobre a Lei $n^{o}$ 13.465/17 (MP 759/2016 - Projeto de Lei de Conversão $n^{o}$ 12/2017). Secretaria de Política Agrária da CONTAG, Brasília, jul. 2017. Disponível em: <https://bit.ly/2KimQQ1>. Acesso em: 20 nov. 2018.
} 
beneficiários do programa, tendo em vista que, além da concessão dos créditos e dos serviços de georreferenciamento, prevê a viabilização de meios de acesso, escoamento de produção, energia elétrica, abastecimento de água e de moradia.

Saliente-se, ainda, que a consolidação poderá ocorrer mesmo com metade dos beneficiários à espera da concessão dos créditos de que tem direito, na forma do inciso II da norma transcrita.

Concluídos os investimentos e consolidado o assentamento, portanto, o INCRA não mais se responsabiliza pelas carências ainda observadas no assentamento, delegando-as a cargo dos entes federativos competentes, o que acarreta em assentamentos absolutamente abandonados, sem as garantias básicas e que inviabilizam a permanência e desenvolvimento das famílias no local. Com os títulos definitivos em mãos, a partir da consolidação, as terras de assentamentos em total desconformidade com as necessidades básicas dos beneficiários tendem a retornar ao mercado de terras, contribuindo com uma reconcentração de terras, objetivo oposto à mais basilar ideia do que é a reforma agrária.

\subsubsection{Titulação dos lotes}

Outra alteração trazida com o advento da Lei 13.465/17 e, principalmente, com o Decreto 9.311/2018 foi o privilégio concedido à titulação em títulos de domínio individuais, em detrimento dos contratos de Concessão de Direito Real de Uso aos beneficiários do programa de reforma agrária.

Inicialmente, cabe traçar uma diferenciação teórica entre os diferentes tipos de titulação possíveis aos assentados.

Após ingressar com a ação de desapropriação para fins de reforma agrária da propriedade cujo descumprimento da função social foi comprovado ao longo de procedimento administrativo e alvo de decreto do Presidente da República, o INCRA deverá ser imitido na posse do imóvel no 
prazo de até quarenta e oito horas, nos termos do art. $6^{\circ}$, I da Lei Complementar $\mathrm{n}^{\mathrm{o}} 76$ de 1993.

A partir de então, está a autarquia federal autorizada a iniciar o Projeto de Assentamento (PA), inclusive com a seleção dos beneficiários do Programa Nacional de Reforma Agrária que receberão lotes naquele imóvel.

Tão logo os beneficiários são homologados pelo instituto, é celebrado Contrato de Concessão de Uso (CCU), instrumento de natureza obrigacional administrativa pelo qual órgão ou entidade da Administração Pública faculta ao particular a utilização privativa de bem público, para que a exerça conforme a sua destinação e finalidade (Di Pietro, 2009, p. 694). Frise-se que é essencial a essa modalidade de contrato administrativo o exercício da finalidade pela qual o poder concedente facultou ao particular a utilização daquele imóvel.

Nesse caminhar, cumpre indicar apontamento sobre particularidade fundamental do contrato em análise feita pelos Procuradores da autarquia federal em obra de interpretação da 8.629/93/93 ${ }^{31}$, publicada em 2011, portanto, antes do advento da Lei 13.465/17:

No contrato de concessão de uso, o Estado continua figurando como detentor do domínio, mantendo-se na posse indireta do imóvel. Nessa hipótese, transferirá ao particular apenas a posse direta do bem, a fim de que o mesmo explore a terra, garantindo o sustento de sua família.

Outrossim, seguindo para o caput do art. 18 da Lei 8.629/93/93, inalterado pela nova lei de regularização fundiária, a distribuição dos lotes ocorrerá através da celebração de Contrato de Concessão de Uso (CCU), outorga de Títulos de Domínio (TD) ou Concessão de Direito Real de Uso (CDRU).

31 INSTITUTO NACIONAL DE COLONIZAÇÃO E REFORMA AGRÁRIA, Procuradoria Federal Especializada junto ao Incra. Lei $8629 / 93$ comentada por procuradores federais: uma contribuição da PFE/Incra para o fortalecimento da reforma agrária e do direito agrário autônomo. Brasília, DF, 2011, p. 162. 
O CCU deverá ser concedido na forma do $§ 2^{\circ}$ do art. 18 da 8.629/93, vejamos:

$\S 2^{\underline{0}} \mathrm{Na}$ implantação do projeto de assentamento, será celebrado com o beneficiário do programa de reforma agrária contrato de concessão de uso, gratuito, inegociável, de forma individual ou coletiva, que conterá cláusulas resolutivas, estipulando-se os direitos e as obrigações da entidade concedente e dos concessionários, assegurando-se a estes o direito de adquirir título de domínio ou a CDRU nos termos desta Lei.

O parágrafo seguinte alcança as demais hipóteses de titulação, que poderão ser estabelecidas a partir da medição e demarcação do imóvel, vejamos:

§ 3o O título de domínio e a CDRU conterão cláusulas resolutivas e será outorgado ao beneficiário do programa de reforma agrária, de forma individual ou coletiva, após a realização dos serviços de medição e demarcação topográfica do imóvel a ser alienado.

Vale dizer que, como indicado anteriormente, a titulação é elemento essencial para a consolidação dos assentamentos, seja através da CDRU seja do TD.

O título de domínio é entendido como modo especial de alienação do bem público, transferindo-se a titularidade ao patrimônio privado. Tal outorga deve ser formalizada por escritura pública ou termo administrativo, levados a registro no Cartório de Registro de Imóveis ${ }^{32}$. Cumpre ressaltar que, mesmo nessa modalidade de titulação, deverá constar do instrumento cláusula de inalienabilidade de dez anos, na forma do $\S 1^{\circ}$ do art. 18 da Lei 8.629/93, contados a partir da concessão do CCU.

O CDRU, por sua vez, segundo Hely Lopes Meirelles (2009, p. 537), consiste em um

32 INSTITUTO NACIONAL DE COLONIZAÇÃO E REFORMA AGRÁRIA, Procuradoria Federal Especializada junto ao Incra. Lei 8629/93 comentada por procuradores federais: uma contribuição da PFE/Incra para o fortalecimento da reforma agrária e do direito agrário autônomo. Brasília, DF, 2011, p. 162-163 
contrato pelo qual a Administração transfere o uso remunerado ou gratuito de um terreno público a particular, como direito real resolúvel, para que dele se utilize em fins específicos de urbanização, edificação, cultivo ou qualquer outra exploração de interesse social.

Assim, enquanto o CCU tem natureza obrigacional administrativa, o CDRU ganha contornos e natureza de direito real, com caráter eminentemente social de regularização fundiária.

O título de domínio, nesse sentido, não carrega necessariamente a obrigação de cumprimento da finalidade a que era inicialmente vinculado, configurando, como ressaltando, uma transferência de propriedade pública ao particular, que passa de assentado a proprietário de imóvel rural, podendo aliená-lo a terceiros e, assim, contribuir com a reconcentração de terras.

Essa é uma das críticas mais fundamentais a essa modalidade de titulação, funcionando como um dos principais motivos para que os movimentos sociais de luta pela terra apoiem e incentivem a outorga de CDRU ao invés da titulação definitiva.

Todavia, remando em sentido contrário ao que defendem os mencionados coletivos, o Decreto 9.311/2018 estabelece claro privilégio a titulação definitiva, em movimento que, como veremos, já vinha ocorrendo mesmo anos antes da publicação da lei ou do próprio decreto regulamentador.

As normativas que regulamentam a titulação de beneficiários do Programa Nacional de Reforma Agrária vêm apontadas no artigo 24 do Decreto 9.311, indicando que a CCU deverá ser outorgada provisoriamente aos beneficiários e a CDRU ou título de domínio de forma definitiva.

Nesse caminhar, em seu $\S 4^{\circ}$ determina que a titulação por meio de CDRU, seja individual ou coletiva, assim como através de TD coletivo, somente poderá ser concedido quando for a modalidade requerida por, no mínimo, cinquenta por cento dos beneficiários do projeto de assentamento. Vejamos o que prescreve o mencionado $§ 4$ do art. 24 do Decreto 9.311/2018: 
$\S 4^{\circ}$ A titulação definitiva por meio de CDRU, individual ou coletivo, ou por meio de TD coletivo somente será concedida quando requerida por, no mínimo, cinquenta por cento dos beneficiários de um mesmo projeto de assentamento, conforme disciplinado pelo Incra.

O parágrafo, assim, inova no ordenamento jurídico, aprofundando prática já consolidada na autarquia federal, onde foram observadas orientações e incentivos para a outorga do máximo possível de títulos de domínio em detrimento de CDRU.

Um dos principais incentivos desse tipo é o "titulômetro", sistema divulgado em reportagem da Repórter Brasil ${ }^{33}$, publicado em 04 de outubro de 2017, que apontava:

Desde abril, servidores do Instituto Nacional de Colonização e Reforma Agrária (Incra) recebem incentivos para dar títulos individuais de propriedade da terra ao maior número possível de assentados da reforma agrária. Quando ligam seus computadores, encontram na tela o titulômetro, nome oficial de um ranking que fixa metas e premia as superintendências regionais que mais emitem esses títulos. Como prêmio mensal, a equipe 'medalha de ouro' ganha 8 notebooks; a de 'prata', 6 , e a de bronze, 4 .

A matéria indica ainda importante crítica a esse tipo de orientação, qual seja, a inversão de valores promovida pela autarquia federal ao incentivar a titulação individual: busca a multiplicação de proprietários rurais, em detrimento de seu objetivo primordial que era a criação, o desenvolvimento e o fortalecimento de assentamentos rurais.

Nesse caminhar, vale indicar o quadro elaborado pela reportagem, com fonte nos dados do INCRA, que estampa o já visível resultado de tal política:

${ }^{33}$ GUERRA, Renata; MAGALHÃES, Ana. Titulômetro e cortes no Incra esvaziam política de reforma agrária. Repórter Brasil, São Paulo, 4 out. 2017. Disponível em: <https://bit.ly/2DOOUKt>. Acesso em: 20 nov. 2018. 


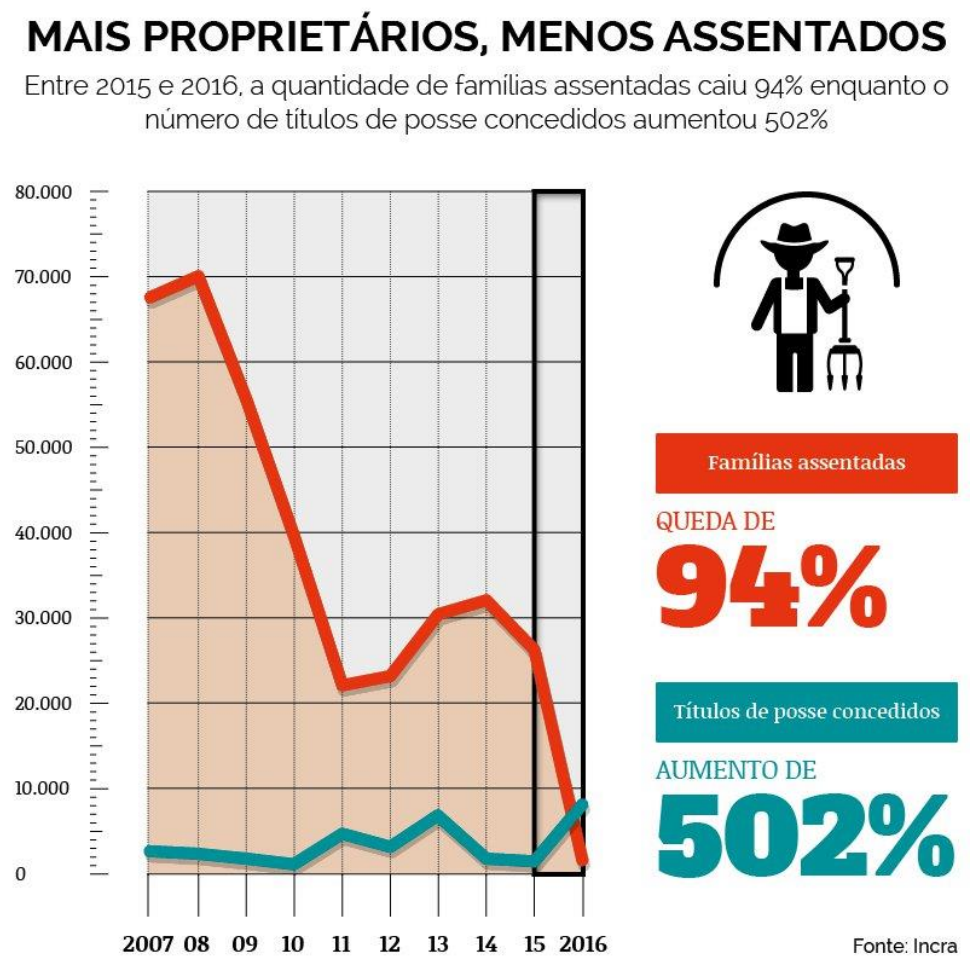

Nesse ponto, cumpre indicar a crítica feita por Julianna Malerba (2018, online), que aponta, como a reportagem, que a política de incentivos à titulação dos beneficiários, em detrimento da garantia das condições adequadas aos assentados, vem ocorrendo desde antes do advento da nova lei de regularização fundiária e, por óbvio, do Decreto, demonstrando que os novos dispositivos vieram para aprofundar essa política já implementada pelo órgão:

Os dados evidenciam que a prioridade da atual política agrária é produzir mais proprietários e menos assentados, tendência que já vinha sendo traçada antes do golpe. Entre 2015 e 2016, o número de famílias assentadas caiu de 26.335 para 1.686, chegando em 2017, justamente quando o INCRA bate o recorde de titulações, a zero. Ou seja, enquanto milhares de títulos são concedidos, nem uma só família foi assentadavi. Não por acaso, o valor destinado à obtenção de terras para a reforma agrária para 2018, segundo o PLDO, teve uma redução de $84 \%$ e contará com R \$ 34,2 milhões. A título de comparação, em 2015, ano em que o número de criação de assentamentos já estava em queda, os recursos para obtenção de terras para reforma agrária totalizaram $\mathrm{R} \$ 800$ milhões.

Antes, o INCRA só emitia títulos aos assentados depois de comprovar a autossuficiência dos assentamentos com o objetivo de justamente evitar que essas terras voltassem rápido ao mercado e gerassem reconcentração fundiária. A nova política - que conta até com incentivo de meta de titulação às superintendências 
regionais e que ficou conhecido como titulômetro - vai em sentido inverso. Ao conceder títulos de domínio sem que sejam aferidas as condições de reprodução econômica do assentamento, o que o governo faz é se isentar de um eixo estruturante da reforma agrária: garantir políticas de infraestrutura e apoio para que os agricultores produzam e permaneçam na terra.

Nessa toada, torna-se fundamental ressaltar que a alienação dos títulos de domínio após atingido o prazo de inalienabilidade de dez anos, encontra como único obstáculo a vedação do art. $22, \S 1^{\circ}$ da Lei $8.629 / 93^{34}$, qual seja, a nova área titulada não poderá integrar imóvel rural com área superior a quatro módulos fiscais, não importando, portanto, se o comprador atingiria os critérios para beneficiários do PRNA.

Traçando necessário paralelo entre a titulação, a consolidação do projeto de assentamento e as formas de titulação, vale ressaltar que a titulação individual contribui para a descaracterização do sentimento de coletividade necessário para a pressão do poder público na concessão de créditos e garantia de acesso ao saneamento básico, luz elétrica, rede de transporte, etc.

A partir do momento em que ocorre a consolidação em títulos individuais de domínio, como privilegiado pela nova regulamentação, o INCRA delega aos entes federativos competentes a garantia de tais direitos, o que aponta para a importância de assentados coordenados e alinhados para pressionar o poder público, movimento extremamente dificultado pela desarticulação de proprietários individuais.

Finalmente, impede ressaltar que, coadunando o novo marco do requisito da temporalidade enquanto elemento único para a consolidação do assentamento, inclusive com a possibilidade de fazê-lo com apenas metade dos beneficiários com o crédito efetivamente concedido, em um cenário de desarticulação e desamparo das famílias, com a possibilidade de alienação do título em dez anos, observa-se um importante indicativo para a consequência

\footnotetext{
$34 \S 1^{\circ}$ Após transcorrido o prazo de inegociabilidade de dez anos, o imóvel objeto de título translativo de domínio somente poderá ser alienado se a nova área titulada não vier a integrar imóvel rural com área superior a quatro módulos fiscais.
} 
devastadora do arcabouço da nova regulamentação cuja maior faceta está na realização de verdadeira contrarreforma agrária, com a venda dos títulos individuais em vista da vasta precarização dos assentamentos rurais.

\subsubsection{Seleção de beneficiários do programa de reforma agrária e a municipalização do procedimento}

Tendo como principal base argumentativa irregularidades apontadas em acórdãos do Tribunal de Contas da União, foram promovidas uma série de alterações na regulamentação de seleção e permanência dos beneficiários do Programa Nacional de Reforma Agrária.

Em decisão publicada em abril de 2016 (Acórdão n 775/2016), o Tribunal de Contas da União conheceu representação formulada pela Secretaria de Controle Externo da Agricultura e do Meio Ambiente, que apontava indícios de irregularidades na seleção de beneficiários do mencionado programa.

Assim, foi deferido, em Medida Cautelar, a suspensão de processos de seleção de novos beneficiários para a Reforma Agrária, de processos de assentamento de novos beneficiários, de processos de novos pagamentos de créditos da Reforma Agrária para beneficiários com indícios de irregularidade e a remissão dos pagamentos feitos, de acesso aos serviços de assistência técnica e extensão rural, bem como do acesso a outros benefícios e políticas públicas concedidas em função do beneficiário fazer parte do PNRA, à exemplo do Minha Casa Minha Vida - Habitação Rural, o Programa de Aquisição de Alimentos, Bolsa Verde, Pronera e Programa de Assistência Técnica e Extensão Rural.

Posteriormente outros acórdãos do mesmo tribunal flexibilizaram as suspensões impostas, em especial o Acórdão no 1976/2017, mas continuava desfavorecendo a retomada de ações da reforma agrária (Leite \& Sauer, 2017b, p.3). 
Nessa toada, segundo o governo em resposta às exigências do TCU, a seleção dos beneficiários passa a ser realizada através de editais, a serem promovidos em conjunto com o município em que faz parte o imóvel objeto do programa. Tal previsão se deu pela inclusão do $\S 1^{\circ}$ ao art. 19 da Lei 8.629/93:

$\S 1$ o O processo de seleção de que trata o caput deste artigo será realizado pelo Incra com ampla divulgação do edital de convocação na internet e no Município em que será instalado o projeto de assentamento, bem como nos Municípios limítrofes, na forma do regulamento.

Quanto a municipalização do procedimento, observada no parágrafo acima transcrito, vale ressaltar o grave problema que envolve o aumento da possibilidade de ocorrem maiores desmandos em poderes regionais do que a partir da concentração de tal atividade na autarquia federal.

Ora, em justamente em tais espaços que "chefes locais" podem exercer maior influência na escolha de beneficiários, inclusive com eventual troca de favores, o que em muito se afasta da aclamada "diminuição da subjetividade" do procedimento por edital, na forma alardeada pelo governo.

Sem falar de dar-lhes a chance de funcionar não como propulsores de uma seleção célere e justa para impulsionar os projetos de assentamentos na região, mas, ao contrário, funcionarem como bloqueadores do avanço de tais políticas, no caso de serem contrários a efetivação da reforma agrária. É justamente o que levanta a CONTAG em seu parecer sobre a Lei 13.465/17:

Ainda nesse contexto de municipalização da seleção de beneficiários, é sabido que forças locais contrárias à reforma agrária que possuem grande influência sobre os poderes públicos farão o que puder para impedir o avanço da reforma agrária, atuando para desmoralizar os grupos e movimentos que lutam pela terra.

Feitas as necessárias observações sobre a problemática municipalização do processo de seleção dos beneficiários, passemos a 
incursionar pela senda da ordem de preferência, na forma prescrita pelo mencionado art. 19, que ora se transcreve:

Art. 19. O processo de seleção de indivíduos e famílias candidatos a beneficiários do Programa Nacional de Reforma Agrária será realizado por projeto de assentamento, observada a seguinte ordem de preferência na distribuição de lotes:

I - ao desapropriado, ficando-lhe assegurada a preferência para a parcela na qual se situe a sede do imóvel, hipótese em que esta será excluída da indenização devida pela desapropriação;

II - aos que trabalham no imóvel desapropriado como posseiros, assalariados, parceiros ou arrendatários, identificados na vistoria;

III - aos trabalhadores rurais desintrusados de outras áreas, em virtude de demarcação de terra indígena, criação de unidades de conservação, titulação de comunidade quilombola ou de outras ações de interesse público;

IV - ao trabalhador rural em situação de vulnerabilidade social que não se enquadre nas hipóteses previstas nos incisos I, II e III deste artigo; V - ao trabalhador rural vítima de trabalho em condição análoga à de escravo; VI - aos que trabalham como posseiros, assalariados, parceiros ou arrendatários em outros imóveis rurais;

VII - aos ocupantes de áreas inferiores à fração mínima de parcelamento.

Desde logo, vale ressaltar que foi adicionada nova etapa burocrática para a verificação da condição de vulnerabilidade do candidato prevista no inciso IV. Com o advento da Lei 13.465/17, torna-se necessária sua inscrição no Cadastro Único para Programas Sociais do Governo Federal (CadÚnico), ou em outro cadastro equivalente definido em norma regulamentar, na forma do $\$ 5^{\circ}$ do art. 19 da Lei $6.829^{35}$.

É fundamental ressaltar a inclusão em primeiro lugar da ordem de preferência do proprietário desapropriado, de modo que fica a este fica assegurado a preferência para a parcela onde se situa a sede do imóvel (inciso I).

Trata-se, portanto, de um nítido afastamento da noção de desapropriação-sanção, espírito marcante, como vimos, da Constituição de 1988, ao determinar que aquele que descumprisse a função social da

\footnotetext{
35 § 50 A situação de vulnerabilidade social do candidato a que se refere o inciso IV do caput deste artigo será comprovada por meio da respectiva inscrição no Cadastro Único para Programas Sociais do Governo Federal (CadÚnico), ou em outro cadastro equivalente definido em regulamento.
} 
propriedade seria desapropriado para fins de reforma agrária, recebendo a indenização em títulos da dívida agrária (art. 184 CRFB/88).

Ademais, há um evidente risco de aumento de conflitos fundiários e tensões sociais entre os assentados e o antigo proprietário, o que jamais poderia ser legitimado ou propiciado, como é o caso, pelo poder público.

No que concerne a ordem de classificação dos beneficiários, elenca o artigo $19-\mathrm{A}^{36}$ uma série de elementos, dos quais apenas em quarto lugar se encontram as famílias ou indivíduos integrantes de acampamento situado no Município em que se localize a área objeto do projeto de assentamento ou nos Municípios limítrofes (inciso IV), em total desvalorização aos acampamentos rurais como instrumentos históricos de luta, articulação e pressão por reforma agrária.

\subsubsection{Contratos de Integração}

Seguindo nas inovações trazidas pela lei de regularização fundiária objeto do presente estudo, a nova lei trouxe ao artigo 21 da Lei 8.629/93 um parágrafo único que autoriza a celebração de contrato de integração pelas famílias beneficiárias, na forma da Lei 13.288/16.

O referido contrato visa, conforme o art. $2^{\circ}$, I da citada lei competente, estabelecer:

\footnotetext{
${ }^{36}$ Art. 19-A. Caberá ao Incra, observada a ordem de preferência a que se refere o art. 19, classificar os candidatos a beneficiários do Programa Nacional de Reforma Agrária, segundo os seguintes critérios: I - família mais numerosa cujos membros se proponham a exercer a atividade agrícola na área objeto do projeto de assentamento; II - família ou indivíduo que resida há mais tempo no Município em que se localize a área objeto do projeto de assentamento para o qual se destine a seleção, ou nos Municípios limítrofes; III - família chefiada por mulher; IV - família ou indivíduo integrante de acampamento situado no Município em que se localize a área objeto do projeto de assentamento ou nos Municípios limítrofes; V - filhos que tenham entre dezoito e vinte e nove anos idade de pais assentados que residam na área objeto do mesmo projeto de assentamento; VI - famílias de trabalhadores rurais que residam em área objeto de projeto de assentamento na condição de agregados; e VII - outros critérios sociais, econômicos e ambientais estabelecidos por regulamento, de acordo com as áreas de reforma agrária para as quais a seleção é realizada.
} 
relação contratual entre produtores integrados e integradores que visa a planejar e a realizar a produção e a industrialização ou comercialização de matéria-prima, bens intermediários ou bens de consumo final, com responsabilidades e obrigações recíprocas estabelecidas em contratos de integração.

Há, nesse sentido, uma permissão de que empresários do agronegócio funcionem como produtores integradores dessa família, desvinculando a necessidade de trabalho direto dos familiares na produção rural e incluindoa na cadeia de produção do agronegócio, como destaca Flavia Trentini (2017, online):

Importante observar que, diferentemente dos contratos típicos já existentes (parceria e arrendamento), o contrato de integração não regula relações que têm como objeto central a cessão do imóvel rural, mas, sim, a matéria-prima, ou seja, as atividades que implicam o desenvolvimento de um ciclo biológico animal ou vegetal a suprir a demanda agroindustrial. Verifica-se claramente a consolidação jurídica da empresa agrária, que, neste caso, passa a ser integrante do agronegócio, ou seja, está envolvida com outra empresa responsável pelo processamento, distribuição e consumo dos produtos agropecuários in natura ou industrializados.

O cenário aventado pela celebração de tais contratos, no entanto, indica um novo distanciamento da nova regularização fundiária do espírito original da lei fundiária que, como destaca Acácio Zuniga Leite e Sérgio Sauer (2017a, p. 26), "associava o direito à terra ao compromisso da família de cultivá-la, proibindo sua cedência e uso por terceiros".

Finalmente, cumpre mencionar que o contrato de integração não pode ser confundido com a importante possibilidade de formação de cooperativas, forma de organização fundamental para organização e escoamento da produção dos agricultores familiares. Já no parágrafo único do art. $1^{\circ}$ a lei própria prescreve que a integração entre cooperativas e seus associados ou entre cooperativas constitui ato cooperativo, regulado por legislação própria. 


\subsubsection{Pagamento em dinheiro na compra e venda de imóveis para reforma agrária}

Outra novidade trazida com o advento da Lei 13.465/17 foi a autorização do pagamento em dinheiro pelos imóveis adquiridos por compra e venda ou arrematação judicial destinados à implementação de projetos integrantes do Programa Nacional de Reforma Agrária. Vejamos o que prescreve o $\$ 7^{\circ}$, incluído pela lei ao artigo $5^{\circ}$ da Lei 8.629/93:

$\S 7$ ํ $\mathrm{Na}$ aquisição por compra e venda ou na arrematação judicial de imóveis rurais destinados à implementação de projetos integrantes do Programa Nacional de Reforma Agrária, o pagamento poderá ser feito em dinheiro, na forma estabelecida em regulamento.

A análise de mais esta inovação trazida pela nova lei de regularização fundiária, deve ser feita a partir de uma reflexão sobre o espírito da nova lei de regulamentação fundiária, onde é objetivada uma inserção do Incra no mercado de negociação de terras, reproduzindo uma lógica de mercantilização de terras, afastando a reforma agrária das diversas temáticas políticas que a envolve e filiando-se a ideia de que o Estado é mais um negociador de terras que deve ter paridade de armas com os demais atores desse mercado, desconsiderando os problemas do sistemático descumprimento da função social e a concentração de terras no país.

O mencionado parágrafo inova ao permitir o pagamento em dinheiro na compra e venda ou arrematação judicial de terras para fins de reforma agrária, em detrimento do que prescreve o artigo 184 da Constituição Federal, que determina a desapropriação de imóveis descumpridores de sua função social para o mesmo fim.

A Magna Carta, nesse sentido, privilegia uma perspectiva mais ampla sobre a questão rural, entendendo a função social como elemento formador do direito de propriedade e a desapropriação daqueles que a descumprem como forma de sanção e garantia da devida destinação à esse imóvel rural 
através de sua utilização para fins de reforma agrária. São elementos que dialogam fortemente, ao contrário do que transações em dinheiro desencadeiam.

A principal argumentação do governo na defesa de tal previsão, é que enseja ao Incra concorrer em condições iguais no mercado de terras, o que possibilitaria a aquisição de terras em melhores condições.

Todavia, as críticas tecidas pela CONTAG em parecer próprio ${ }^{37}$ merecem destaque:

a) eliminação total de qualquer possibilidade de sanção ao latifúndio e à propriedade que não cumprir a função social;

b) o INCRA será um balcão de negócios de terra, já que ela será transformada num ativo financeiro bastante atrativo (em especial com a estrangeirização);

c) ausência de recursos pelo Estado - a proposta se torna contraditória, especialmente quando o governo reduz o orçamento para a Reforma Agrária, e desmonta os órgãos que a executam, além do congelamento de investimentos públicos por 20 anos.

Em primeiro lugar, ressaltam o que já foi levantado anteriormente no presente trabalho, qual seja, o afastamento da nova legislação dos princípios basilares que constituem a noção de reforma agrária a partir do marco constitucional em especial da ideia de que a reforma agrária deverá ser promovida através da desapropriação de imóveis rurais descumpridores de sua função social para fins de reforma agrária, sendo a natureza de tal ato eminentemente sancionatória pelo descumprimento da finalidade socioambiental da propriedade. A compra de imóveis, em iguais condições dos demais atuantes no mercado de terra, descaracteriza a atuação do poder público investido na persecução de tais alicerces que constituem a própria noção de reforma agrária no Brasil.

De igual forma, o segundo elemento aduzido pela entidade foi a transformação da autarquia federal em um verdadeiro balcão de negócios,

\footnotetext{
${ }^{37}$ Notas Sobre a Lei $n^{\circ}$ 13.465/17 (MP 759/2016 - Projeto de Lei de Conversão $n^{\circ}$ 12/2017). Secretaria de Política Agrária da CONTAG, Brasília, jul. 2017, p. 5. Disponível em: <https://bit.ly/2KimQQ1>. Acesso em: 20 nov. 2018.
} 
contribuindo com a mercantilização da terra e, novamente, se afastando dos seus objetivos iniciais para posicionar-se lado a lado dos demais atores de tal estrutura comercial, enxergando a terra como um ativo financeiro e aprofundando tais concepções.

O terceiro e último ponto ressaltado no parecer foi a evidente incongruência que se coloca com o desmonte de políticas públicas promovido no mesmo momento em que o Incra se posicionaria "de igual para igual" como negociador no mercado de terras, indicando a aquisição de imóveis como método possível para efetivação da reforma agrária, sem, contudo, possuir os necessários recursos para tanto.

\subsection{Ação Direta de Inconstitucionalidade (ADI 5771)}

Pouco mais de um mês após a publicação da Lei 13.465, em 11 de julho de 2018, o Procurador Geral da República, legitimado universal para a propositura de Ação Direta de Inconstitucionalidade, manejou o citado instrumento de controle de constitucionalidade tendo como objetivo a declaração de inconstitucionalidade da referida lei.

Inicialmente, muito se discorreu a respeito da violação aos requisitos constitucionais de relevância e urgência para edição de Medida Provisória, na forma do art. 62 da Constituição Federal, o que não teria ocorrido in casu. Vale mencionar que o PGR, nesse ponto, ressaltou que alguns dos motivos levantados pelo governo para embasar a relevância e urgência do tema atravessaram diversos momentos do histórico sem que fossem efetivamente solucionados, de modo que não se justificaria tamanha urgência do dia para a noite:

Grilagem de terras e desmatamento atravessaram séculos até aqui, literalmente, sem soluções de todo satisfatórias. Não é concebível que, de um momento para o outro, se transformem em problemas de tamanha urgência que demandem uso do instrumento excepcional e urgente que é a medida provisória, com usurpação da função legislativa ordinária do Congresso Nacional. 
Ademais, importante argumento aduzido para afastar o periculum in mora é de que parte importante da matéria que se objetiva normatizar pende de regulamentações futuras, atualmente já consolidadas a partir, em especial, no que nos toca, dos Decretos 9.311, de 15 de março de 2018, e Decreto 9.424, de 26 de junho de 2018. De todo modo, a necessidade de posterior regulamentação é claro indicativo de que não se estava diante de quadro de real necessidade e urgência a justificar a edição de Medida Provisória tão vasta e, como veremos, avassaladora.

Outro fundamental elemento levantado foi a "grave distorção do sistema democrático e desrespeito à função legislativa" observado no caso em análise, tendo em vista que a Medida Provisória modifica mais de uma dezena de leis aprovadas pelo Congresso Nacional, possuindo diversas delas mais de uma década de vigência e fruto de processos legislativos que envolveram larga participação popular, o que certamente não se pode falar da edição de uma MP. O Procurador aponta, nessa toada, para um desvirtuamento decorrente de edição imprópria de MPs, o que desfigura a relação institucional entre os poderes ao conferir inconstitucional proeminência ao Executivo.

Outrossim, desde logo desenha o Autor uma verdadeira listagem de afrontas da Lei aos princípios e regras constitucionais, quais sejam:

A Lei 13.465/2017, além de ser fruto de medida provisória destituída dos requisitos constitucionais de relevância e urgência (art. 62, caput), afronta múltiplos princípios e regras constitucionais, como o direito a moradia (art. 6o), o direito a propriedade e o cumprimento de sua função social (art. 5o, caput e inciso XXIII), a proteção do ambiente (art. 225, caput, §1o, I, II, III e VII, e §§ 2 o e 4o), a política de desenvolvimento urbano (art. 182, caput e $\S \S 1$ o e 2o), o dever de compatibilizar a destinação de terras públicas e devolutas com a política agrícola e o plano nacional de reforma agrária (art. 188, caput), os objetivos fundamentais da República (art. 3o, I a III), a proibição de retrocesso, o mínimo existencial e o princípio da proporcionalidade (na faceta de proibição da proteção deficiente), a competência constitucionalmente reservada a lei complementar (art. $62, \S 10$, III), a competência da União para legislar sobre Direito Processual Civil (art. 62, I, $b$ ), a previsão de que o pagamento de indenizações da reforma agrária será em títulos da dívida agrária (art. 184, caput), a exigência de participação popular no planejamento municipal (art. 29, XII) e as regras constitucionais do usucapião especial urbano e rural (arts. 183 e 191). 
Assim, além da inconstitucionalidade formal observada pela ausência dos requisitos de urgência e relevância para edição de MP e das inconstitucionalidades materiais indicadas na citação trazida, outra inconstitucionalidade formal foi levantada pelo Autor da ação em análise: a regularização de matéria de lei complementar e de Processo Civil, tendo em vista que o art. 109 da Lei 13.465/17 revoga os arts. 14 e 15 da Lei Complementar $n^{\circ} 76 / 93$, que regula o procedimento contraditório especial de rito sumário para desapropriação para fins de reforma agrária de imóveis rurais.

Ocorre que, como dito, a regulamentação da matéria é reservada a lei complementar (art. $184, \S 3^{\circ}$ da CRFB/ $88^{38}$ ), de modo que sua alteração por Medida Provisória é manifestamente inconstitucional, mesmo com a sua posterior conversão em Lei ordinária.

Sem falar na alteração de incisos do art. 799 da Lei 13.105/15, o Código de Processo Civil, que, sem dúvidas, não poderia ser feita através de Medida Provisória, em vista da já citada vedação do art. 62, §1º $, \mathrm{I}, \mathrm{b}$ da $\mathrm{CRFB} / 88^{39}$.

Elencadas as inconstitucionalidades formais aduzidas pelo Procurador Geral da República através de Ação Direta de Inconstitucionalidade, passemos a incursionar pela senda das principais inconstitucionalidades materiais apontadas, focando-se nas discussões sobre as mudanças no campo da reforma agrária trazidas pela nova regulamentação.

Sobre essa questão, aponta o Autor pela desnecessidade de apontar os artigos destacadamente, tendo em vista que "fundamentalmente, ela fere a

\footnotetext{
${ }^{38}$ Art. 184. Compete à União desapropriar por interesse social, para fins de reforma agrária, o imóvel rural que não esteja cumprindo sua função social, mediante prévia e justa indenização em títulos da dívida agrária, com cláusula de preservação do valor real, resgatáveis no prazo de até vinte anos, a partir do segundo ano de sua emissão, e cuja utilização será definida em lei. $\S 3^{\circ}$ Cabe à lei complementar estabelecer procedimento contraditório especial, de rito sumário, para o processo judicial de desapropriação.

${ }^{39}$ Art. 62. Em caso de relevância e urgência, o Presidente da República poderá adotar medidas provisórias, com força de lei, devendo submetê-las de imediato ao Congresso Nacional.

$\S 1^{\circ}$ É vedada a edição de medidas provisórias sobre matéria:

I - relativa a:

b) direito penal, processual penal e processual civil;
} 
Constituição ao tratar de seus temas centrais - regularização fundiária rural, regularização fundiária urbana e desmatamento - em descompasso com numerosas diretrizes que a ordem constitucional estipula.

Nessa toada, são levantados como principais pontos de absoluto desencontro entre a nova norma regulamentadora e o que prescreve a Constituição Federal, para o que nos toca: o direito social à moradia, demonstrando-se que sua utilização na defesa da Medida Provisória foi absolutamente inadequada e subvertida, bem como a regularização fundiária rural imposta vai contra o que estabelece a Magna Carta em seu art. 184, que determina a desapropriação de imóveis rurais para fins de reforma agrária no caso de descumprimento de sua função social, assim como a destinação de terras públicas ou devolutas em compatibilidade com a política agrícola, esta última vinculada a preocupação com a habitação do trabalhador rural, na forma do art. 187, VIII e art. 188 da CRFB/88.

Insta sublinhar, a citação trazida na ação ora em estudo do Relator Especial da ONU para moradia adequada entre 2000 e 2008, Miloon Kothari, que, em informe de 13 de fevereiro de $2008^{40}$, apontou que um dos principais obstáculos à realização do direito à moradia é o tratamento que se dá a moradia, terra e a propriedade enquanto produtos comercializáveis e não como Direitos Humanos, característica patente da nova legislação fundiária, como veremos em seguida. Vale transcrever parte do relatório apontado:

67. A terra constitui o principal ativo que permite aos pobres das zonas rurais assegurar sua subsistência. Sem embargo, estima-se que, de todas as terras do mundo em mãos privadas, quase três quartos estão controladas por apenas 2,5\% de todos os proprietários. Milhões de famílias, mesmo que trabalhem a terra, não têm sua propriedade, e se consideram camponeses sem terra. Em média, 71,6\% das famílias rurais na África, América Latina e Ásia Oriental e Ocidental (exceto China) carecem de terra ou têm muito pouca.

68. A terra desempenha ainda um papel essencial na vinculação estrutural entre os problemas da habitação rural e da habitação urbana. A despeito de a migração

\footnotetext{
${ }^{40}$ KOTHARI, Miloon. Informe del Relator Especial sobre la vivenda adecuada como elemento integrante del derecho a un nivel de vida adecuado y sobre el derecho de no discriminación a este respecto. ONU. Consejo de Derechos Humanos. Promoción y protección de todos los derechos humanos, civiles, políticos, económicos, sociales y culturales, incluido el derecho al desarrollo. A/HRC/7/16, 13 feb. 2008, p. 20-21. Disponível em: 〈http://bit.ly/2gnqGN6>. Acesso em 20 nov. 2018.
} 
para as zonas urbanas estar em aumento, não se abordam as causas subjacentes a esse fenômeno. Essa migração geralmente não é voluntária, mas o resultado da extrema pobreza rural como consequência da carência de terra; a insegurança da posse da terra; a utilização da terra para outros fins; a perda dos meios de subsistência por não ter se dado prioridade à reforma agrária ou por não se haverem promovido as infraestruturas rurais; os deslocamentos provocados por projetos de desenvolvimento; as moradas de ínfima qualidade; ou a utilização de terras de cultivo para usos industriais. A falta de reconhecimento legal do direito à terra contribui para essas situações. Nas cidades, impede-se a esses migrantes, com frequência, acesso a moradia adequada e se os obriga a viver em bairros de casebres e outros assentamentos improvisados que se caracterizam pela insegurança e condições de vida inadequadas.

69. As desigualdades na propriedade das terras e a carência de terras geram uma série de problemas inter-relacionados: desde moradias inadequadas até a falta de opções de subsistência, a má saúde, a fome e a insegurança alimentar, ou a pobreza extrema. (...)

Nessa toada, defende o Autor a existência de uma dimensão subjetiva e outra objetiva na política de reforma agrária, tendo em vista que, na primeira delas, concretiza o direito à moradia e, em consequência, densifica o princípio da dignidade humana, ao passo que, na segunda faceta, realiza os objetivos que a Constituição define para o Estado.

É justamente nesse passo que se deve resgatar o que prescreve o já mencionado art. 188 da CRFB/88:

Art. 188. A destinação de terras públicas e devolutas será compatibilizada com a política agrícola e com o plano nacional de reforma agrária.

Ao contrário do que determina o artigo, porém, a nova regulamentação fundiária caminha em prejuízo da população do campo, que espera pela concretização de seu direito à moradia e a democratização do acesso à terra, desconcentrando a estrutura fundiária brasileira e incentivando a diversificação da produção agrícola como garantia de alimentação adequada para todos. Trata-se, portanto, de toda uma costura incentivada pelos preceitos constitucionais que é desfeita com a nova lei, privilegiando o reforço da estrutura de concentração fundiária e a transferência de terras públicas e devolutas para o poder privado, com programas abordados em 
pesquisas próprias, mas extremamente abordado por ocasião da ora em análise ADI 5771.

Seguindo aos demais elementos levantados pela Procuradoria Geral da República, vale sublinhar a defesa de que a lei importa em ofensa ao direito ao mínimo existencial, tendo em vista que ampliará o universo de pessoas desfavorecidas e em situação de vulnerabilidade.

Sobre o conceito de mínimo existencial, vale trazer a definição da Corte Constitucional Colombiana transcrita pelo Autor na peça exordial da ação em referência:

O objeto do direito fundamental ao mínimo vital abarca todas as medidas positivas ou negativas constitucionalmente ordenadas com o fim de evitar que a pessoa se veja reduzida em seu valor intrínseco como ser humano devido a não contar com as condições materiais que lhe permitam levar uma existência digna. [...] Tal direito protege a pessoa, em consequência, contra toda forma de degradação que comprometa não só sua subsistência física mas, sobretudo, seu valor intrínseco. [...] Pois bem, o direito fundamental ao mínimo vital apresenta uma dimensão positiva e uma negativa. A dimensão positiva desse direito fundamental pressupõe que o Estado e, ocasionalmente, os particulares [...] estejam obrigados a fornecer, à pessoa que se encontre em uma situação na qual ela mesma não possa atuar autonomamente e que comprometa as condições materiais de sua existência, as prestações necessárias e indispensáveis para sobreviver dignamente e evitar sua degradação ou aniquilamento como ser humano. $(\ldots)^{41}$

Ora, segundo a PGR, há uma afronta ao direito ao mínimo existencial em sua dupla perspectiva, qual seja negativa e positiva, tendo em vista a supressão das condições materiais básicas da população de baixa renda para acesso à vida digna, assim como o descumprimento do dever prestacional do Estado de satisfação dos direitos fundamentais.

Ademais, realçou o Autor o dever de progressividade assumido pelo Brasil no Pacto Internacional sobre Direitos Economicos, Sociais e Culturais (art. $2^{\circ}$, item 1) e no Protocolo de São Salvador (ar. $1^{\circ}$ ), determinação essa

\footnotetext{
41 Corte Constitucional, Colômbia, Sentença C-776, Rel. Juiz Manuel José Cepeda Espinosa. Disponível em: <http://bit.ly/2vBMBTp>. Acesso em: 20 nov. 2018.
} 
que obriga os Estados a adotar medidas para assegurar a progressiva prestação dos direitos sociais.

Nessa esfera, a facilitação de transferência de terras públicas a pessoas de média e alta renda, promovendo a concentração de terras e acentuando a desigualdade, por exemplo, já denota claro sinal do retrocesso marcante da nova regulamentação fundiária.

Além disso, no que nos toca, trata o Autor do descumprimento da função social e ambiental da propriedade, assim como a violação ao princípio da proporcionalidade. Desde logo, ressalta-se que a defesa e melhoria do meio humano para gerações presentes e futuras converteram-se em objetivo imperioso para toda humanidade, tendo em vista o que prescreve a Declaração de Estocolmo (julho de 1972).

Outrossim, sublinha a PGR o que já foi levantado oportunamente no presente trabalho a respeito do princípio da função social da propriedade ser elemento integrador do próprio direito fundamental à propriedade, observando que a lei não contém instrumentos eficazes para deter o descumprimento da função social, em especial o desmatamento, ao contrário, torna ainda mais frágil a proteção ambiental.

Por fim, destaca-se o princípio da vedação a proteção deficiente de bens jurídicos constitucionalmente tutelados, momento em que se afirma que a violação à proporcionalidade não ocorre apenas quando há excesso na atuação estatal, mas também quando esta é manifestamente deficiente, como no caso em análise. Assim, é extremamente grave a exposição pela lei de "bens jurídicos de máxima importância sem razão suficientemente forte que justificasse tal opção ruinosa".

A Ação Direta de Inconstitucionalidade foi então, no dia $1^{\circ}$ de setembro de 2017, distribuída sob relatoria do Ministro Luiz Fux. Apresentadas as informações pertinentes pela Advocacia Geral da União e pelo Presidente do Congresso Nacional, em outubro de 2017, requereram o ingresso na ação na qualidade de amicus curiae a Defensoria Pública do Estado de São Paulo, através do núcleo de $2^{\mathrm{a}}$ instância e Tribunais Superiores 
e do núcleo de habitação e urbanismo, bem como a Comissão Pastoral da Terra (CPT).

Até a apresentação da presente pesquisa, a ADI n 5771 ainda não havia sido julgada pelo Supremo Tribunal Federal.

\section{Conclusão}

O presente trabalho analisou as alterações trazidas pela nova lei de regularização fundiária (Lei 13.465/17), refletindo sobre os elementos que constituem a visão de reforma agrária que embasou os argumentos que motivaram a mudança normativa.

Sendo assim, a reflexão teve início com o exame da perspectiva militar na solução da questão agrária que despontou como importante ponto de discussão no período anterior ao golpe de 1964. Importante ponto dessa investigação encontra-se na modernização conservadora promovida no período da Ditadura Militar, com o advento da empresa rural, inaugurada pelo Estatuto da Terra.

Como apontado, a estratégia militar enxergava o incremento da produtividade pela modernização tecnológica e a reorganização da produção em complexos agroindustriais como norte. Sendo assim, esse momento foi importante marco inicial de grande incentivo a completa industrialização do campo (Linhares \& Silva, 1999, p. 126), tendo em vista que a reforma agrária naquele momento concentrava suas forças no desenvolvimento capitalista do campo, vinculada à crença de que o "atraso" no campo seria superado sem que houvesse a necessidade de realizar efetivamente a reforma agrária (Bruno, 1997, p. 185).

O resultado, como amplamente demonstrado, foi um forte incremento dos conflitos de terra, associado à intensa repressão no campo tanto pelas forças policiais quanto por agentes privados, que gerou altíssimo número de camponeses e militantes assassinados, conforme dados apresentados no 
presente trabalho, extraídos em especial da Comissão Camponesa da Verdade.

No processo constituinte, por sua vez, a disputa entre as diferentes compreensões e desejos em torno da política agrária ganharam novo fôlego, cristalizando no texto constitucional o reconhecimento da vinculação do direito de propriedade ao cumprimento de sua função social (art. $5^{\circ}$, XXII e XXIII, art. 170, III da CRFB/88). Restou, nesse sentido, previsto no texto que os proprietários que desrespeitassem essas condições teriam seus imóveis desapropriados para fins de reforma agrária (art. 186 da CRFB/88).

Por outro lado, foi significativa a vitória dos oponentes aos avanços da política de reforma agrária no que toca a imunização das propriedades consideradas produtivas (art. 185, II da CRFB/88).

O arcabouço jurídico construído pela chamada Constituição Cidadã em conjunto com as normativas que vieram posteriormente, em especial, no que nos toca, a Lei 8.629/93 e a Lei Complementar 76/93, tornaram viável a realização da reforma agrária, mas, como visto, o quadro de concentração da propriedade fundiária não enxergou modificações significativas.

Nesse sentido, percebeu-se, a partir da análise feita do quadro atual da conjuntura agrária, que historicamente não foi realizada uma reforma efetiva nessa estrutura de concentração de terras. O resultado, como visto, é observado, entre outros fatores, na expulsão dos trabalhadores do campo gerando o inchaço das cidades, com todas as suas consequências, assim como no incremento da devastação ambiental (Carter, 2010, p. 60), inclusive com a facilitação da transferência do patrimônio natural brasileiro para o controle estrangeiro (Alentejano, 2011, p. 74), no aumento de conflitos fundiários (Delgado, 2017,p. 22) e na insegurança alimentar (Alentejano, 2011, p. 80).

Sendo assim, não obstante a permanência de tal estrutura, a nova regularização fundiária proposta em uma conjuntura de desmontes de políticas públicas, como sublinhado na presente análise, se apresenta como instrumento agravante desse contexto de precariedade e obstrução à realização da reforma agrária, costurando suas soluções para o cenário atual 
na percepção da terra enquanto mercadoria, colocando o Estado, trabalhadores sem-terra e famílias assentadas enquanto novos atores dessa mesa de negócios.

A começar pelo a inclusão do $\$ 6^{\circ}$ ao art. 17 da Lei 8.629/93, que permite a consolidação dos projetos de assentamentos uma vez atingido o prazo de quinze anos desde a sua implantação. Nessa toada, verificou-se um desejo de consolidação em massa de assentamentos em detrimento a garantia dos direitos fundamentais mais básicos das famílias assentadas. Quando analisa-se a citada inovação com o movimento de incentivo à titulação definitiva, como demonstrado, resta evidente a repercussão na reconcentração fundiária que tais alterações propiciam e fomentam, o que foi fartamente questionado na ADI 5771, como apontado no presente trabalho.

De igual forma, a permissão de realização de contratos de integração, a seleção de beneficiários por edital e a municipalização de procedimentos, em conjunto com as alterações na ordem de preferência e classificação de candidatos e com a permissão de pagamento em dinheiro, evidencia um cenário, como dito, de valorização de uma suposta eficiência do poder público, aproximando a lógica da reforma agrária e dos assentamentos ao mercado de terras.

Observa-se, portanto, uma valorização cada vez mais da "terra como negócio", afastando-se das bases da reforma agrária de fato transformadora da estrutura agrária e das relações no campo, privilegiando a noção de "terra como trabalho" (Pilatti, 1988, p. 40).

Nesse contexto, delineou-se um futuro de reconcentração fundiária que fez com que a lei pudesse ser caracterizada enquanto catalizadora de uma contrarreforma agrária, motivo pelo qual, além de sofrer duras críticas por parte dos movimentos sociais de luta pela terra, foi considerada inconstitucional pelo Procurador Geral da República. 


\section{Bibliografia}

LINHARES, Maria Yedda; SILVA, Francisco Carlos Teixeira. Terra Prometida: uma história da questão agrária no Brasil. Rio de Janeiro: Campus, 1999

MARTINS, José de Souza. Militarização da Questão Agrária. Rio de Janeiro: Vozes, 1984.

BRUNO, Regina. Senhores da terra, senhores da guerra. Rio de Janeiro: Forense Universitária, 1997.

COMISSÃO CAMPONESA DA VERDADE. Relatório final violações de direito no campo. Brasília, DF, 2014, p. 62. Disponível em: <https://bit.ly/2mSEkds>. Acesso em: 19 nov. 2018.

VIANA, Gilney. Camponeses mortos e desaparecidos: excluídos da justiça de transição. Brasília, Secretaria de Direitos Humanos/Presidência da República, 2011

FERNANDES, Bernardo Mançano. Formação e territorialização do MST no Brasil. In: CARTER, Miguel (Org.). Combatendo a desigualdade social: o MST e a reforma agrária no Brasil. São Paulo: UNESP, 2010. p. 161-198. PILATTI, Adriano. Marchas de uma Contramarcha: Transição, UDR e Constituinte. 1988. Dissertação (Mestrado em Direito) - Pontifícia Universidade Católica do Rio de Janeiro. 269 p.

MEDEIROS, Leonilde Sérvolo de. Movimentos sociais no campo, lutas por direitos e reforma agrária na segunda metade do século XX. In: CARTER, Miguel (Org.). Combatendo a desigualdade social: o MST e a reforma agrária no Brasil. São Paulo: UNESP, 2010. p. 113-136.

SILVA, José Afonso da. Curso de Direito Constitucional Positivo. $37^{\mathrm{a}}$ Edição. São Paulo: Malheiros, 2014

SGARBI, Adrian. Introdução a Teoria do Direito. São Paulo: Marcial Pons, 2013. 
CARTER, Miguel. Desigualdade social, democracia e reforma agrária no Brasil. In: CARTER, Miguel (Org.). Combatendo a desigualdade social: o MST e a reforma agrária no Brasil. São Paulo: UNESP, 2010. p. 27-78.

DELGADO, Guilherme Costa. A questão agrária e o agronegócio no Brasil. In: CARTER, Miguel (Org.). Combatento a desigualdade social: o MST e a reforma agrária no Brasil. São Paulo: UNESP, 2010. p. 81-112.

ALENTEJANO, Paulo. Questão agrária no Brasil do século XXI: uma abordagem a partir da geografia. Terra Livre, São Paulo, ano 27, v. 1, n. 36, p. 69-95, jan/jun. 2011.

LEITE, Sérgio et al. Impactos dos assentamentos: um estudo sobre o meio rural brasileiro. São Paulo: UNESP, 2004, 392 p.

LEITE, Acácio Zuniga; SAUER, Sérgio. Medida Provisória 759: descaminhos da reforma agrária e legalização da grilagem de terras no brasil. Retratos de Assentamentos, v.20, n.1, p. 14-40, 2017 a.

LEITE, Acácio Zuniga; SAUER, Sérgio. Lei 13.465 e o decreto que reduzirá a reforma agrária a um negócio: uma minuta para uma análise. Boletim DATALUTA, n. 120, ISSN 2177-4463, dez., 2017 b.

MALERBA, Julianna. Reconcentração fundiária será o maior legado da contrarreforma agrária do governo Temer. Brasil em 5, 2018. Disponível em: <https://bit.ly/2FvHfCF>. Acesso em: 20 nov. 2018.

QUINTANS, Mariana Trotta Dallalana. A magistratura fluminense: seu olhar sobre as ocupações do MST. 2005. Dissertação (Mestrado em Direito) - Pontifícia Universidade Católica do Rio de Janeiro. 215 p. Disponível em: <http://dominiopublico.mec.gov.br/download/teste/arqs/cp077273.pdf>. Acesso em: 19 nov. 2018.

DI PIETRO, Maria Sylvia Zanella. Direito administrativo. $22^{a}$ ed. São Paulo: Atlas, 2009

MEIRELLES, Hely Lopes. Direito Administrativo Brasileiro. 35 ed., Atualizada. São Paulo: Malheiros, 2009. 
TRENTINI, Flavia. Contrato de integração, o novo contrato típico agrário.

Conjur, 2017. Disponível em: <https://bit.ly/2S3GtxU>. Acesso em: 20 nov. 2018. 